Revista Eletrônica de Direito Processual - REDP.

Rio de Janeiro. Ano 12. Volume 19. Número 2. Maio a Agosto de 2018

Periódico Quadrimestral da Pós-Graduação Stricto Sensu em Direito Processual da UERJ

Patrono: José Carlos Barbosa Moreira (in mem.). ISSN 1982-7636. pp. 229-260 www.redp.uerj.br

\title{
FUNDAMENTO E FUNÇÃO DO PROCESSO PENAL: A CENTRALIDADE DO \\ JUÍZO ORAL E SUA RELAÇÃO COM AS DEMAIS FASES DA PERSECUÇÃO PENAL PARA A LIMITAÇÃO DO PODER PUNITIVO ${ }^{1}$
}

\author{
JUSTIFICATION AND FUNCTION OF CRIMINAL PROCEDURE: THE \\ CENTRALITY OF THE ORAL TRIAL AND ITS RELATIONSHIP WITH THE \\ OTHER STAGES OF CRIMINAL PROSECUTION FOR PUNITIVE POWER \\ LIMITATION
}

Vinicius Gomes de Vasconcellos Doutor em Direito pela Universidade de São Paulo, com período de sanduíche na Universidad Complutense de Madrid/ESP (bolsa PDSE/CAPES). Pós-doutorando em Direito pela Universidade Federal do Rio de Janeiro - Rio de Janeiro/RJ. Professor do Mestrado em Direito do Centro Universitário FIEO - OSASCO/SP. Professor da Graduação em Direito das Faculdades Integradas Campos Salles - São Paulo/SP. Editor-chefe da RBDPP e editor-assistente da RBCCRIM. E-mail: vgomesv@gmail.com

lattes.cnpq.br/9628659956663949

orcid.org/0000-0003-2020-5516

RESUMO: Este artigo almeja estudar as etapas da persecução penal e suas funções cognitivas, com o objetivo de, por um lado, verificar a importância da centralidade do juízo oral, e, por outro, a necessidade e a amplitude do respeito aos direitos fundamentais em todas as fases. Assim, espera-se determinar o fundamento e a função do processo penal, que deverão orientar a estruturação da justiça criminal como instrumento de limitação do poder punitivo estatal. A partir de revisão bibliográfica, esta pesquisa pretende responder os seguintes problemas: 1) qual é o fundamento e a função essencial do processo penal?; 2)

\footnotetext{
${ }^{1}$ Artigo recebido em 23/12/2017 e aprovado em 23/03/2018.
} 
Revista Eletrônica de Direito Processual - REDP.

Rio de Janeiro. Ano 12. Volume 19. Número 2. Maio a Agosto de 2018

Periódico Quadrimestral da Pós-Graduação Stricto Sensu em Direito Processual da UERJ

Patrono: José Carlos Barbosa Moreira (in mem.). ISSN 1982-7636. pp. 229-260

www.redp.uerj.br

qual é a relação entre as fases procedimentais do processo penal e a sua função de um modo amplo?; 3) qual é a relação das fases procedimentais do processo penal entre si?

PALAVRAS-CHAVE: Processo penal; fundamento; função; procedimento; limitação poder punitivo.

ABSTRACT: This article intends to analyze the stages of criminal prosecution and its cognitive functions, aiming, on one hand, to verify the importance of the centrality of oral judgment, and, on the other hand, of the necessity to respect fundamental rights at all stages. Thus, it is sought to determine the justification and function of the criminal process, which should guide the structuring of criminal justice as a limitation instrument of the state punitive power. Considering these issues, through bibliographic review, this work will address the following problems: (1) what is the justification and the essential function of criminal procedure? 2) what is the relation between the procedural stages of the criminal process and its function in a wide perspective?; 3) what is the relation between the procedural stages of the criminal process among themselves?

KEY WORDS: Criminal procedure; foundation; function; procedural law; punitive power limitation.

SUMÁRIO: Introdução. 1. As etapas da persecução penal e suas funções cognitivas: sobre a centralidade do juízo oral e as suas relações com as demais fases. 2. A proteção de direitos e garantias fundamentais nas fases da persecução penal: o exemplo do juízo de segundo grau. 3. O fundamento e a função do processo penal como orientação para todas as fases da persecução penal. Considerações finais. Referências bibliográficas.

\section{Introdução}

Considerando a importância das premissas do direito processual penal e a tendência atual de relativização de seus contornos (por exemplo, com os mecanismos de justiça criminal negocial), é fundamental retomar a discussão doutrinária sobre o fundamento e a função do processo penal. Variando desde um mero instrumento para realização do direito 
Revista Eletrônica de Direito Processual - REDP.

Rio de Janeiro. Ano 12. Volume 19. Número 2. Maio a Agosto de 2018

Periódico Quadrimestral da Pós-Graduação Stricto Sensu em Direito Processual da UERJ

Patrono: José Carlos Barbosa Moreira (in mem.). ISSN 1982-7636. pp. 229-260

www.redp.uerj.br

material até um mecanismo de resolução de conflitos e pacificação social, o processo penal é um dispositivo inerente à racionalidade e à concretização do poder punitivo na sociedade.

Nesse sentido, a correta compreensão sobre suas fases essenciais junto à relação entre elas e a proteção de direitos fundamentais caracterizam-se como temáticas indispensáveis para assentar as bases da dogmática processual penal de um Estado democrático de Direito.

Diante disso, por meio de revisão bibliográfica, este artigo pretende analisar as etapas da persecução penal e suas funções cognitivas, com o objetivo de, por um lado, verificar a importância da centralidade do juízo oral, e, por outro, a necessidade e amplitude de respeito aos direitos fundamentais em todas as fases. Assim, almeja-se determinar o fundamento e a função do processo penal, que deverão orientar a estruturação da justiça criminal como instrumento de limitação do poder punitivo estatal. Considerando tais questões, este trabalho responderá os seguintes problemas: 1) qual é o fundamento e a função essencial do processo penal?; 2) qual é a relação entre as fases procedimentais do processo penal e a sua função de um modo amplo?; 3) qual é a relação das fases procedimentais do processo penal entre si?

\section{As etapas da persecução penal e suas funções cognitivas: sobre a centralidade do juízo oral e as suas relações com as demais fases}

Com o objetivo de analisar o processo penal em uma visão ampla, inicialmente impõe-se o estudo das características básicas de cada uma de suas etapas: investigação preliminar, etapa intermediária, juízo oral e juízo recursal. ${ }^{2}$ Por certo, cada um desses pontos justificaria estudos específicos e profundos, de modo que neste artigo se buscará definir os aspectos essenciais de suas funções, para possibilitar a problematização sobre o impacto de tais premissas na configuração procedimental da respectiva etapa em relação ao respeito às regras do devido processo penal.

Segundo Daniel Pastor, a estruturação da justiça criminal em dois graus, com um juízo recursal que autorize uma revisão ampla da sentença, contribui para o sistema de

\footnotetext{
${ }^{2}$ FERNANDES, Antonio Scarance. Teoria Geral do Procedimento e O Procedimento no Processo Penal. São Paulo: RT, 2005. p. 34-36. O autor, contudo, opta por dividir a persecução em quatro fases, sem considerar a esfera recursal: investigação, formulação e admissibilidade, instrutória e de julgamento. Contudo, neste artigo, considerando o seu objeto, adota-se visão mais ampla, estruturando a persecução em quatro etapas fundamentais, de modo a incluir o juízo impugnativo. Além disso, exclui-se a execução penal, pois trata-se de fase posterior à verificação da pretensão acusatório por meio da produção probatória.
} 
Revista Eletrônica de Direito Processual - REDP.

Rio de Janeiro. Ano 12. Volume 19. Número 2. Maio a Agosto de 2018

Periódico Quadrimestral da Pós-Graduação Stricto Sensu em Direito Processual da UERJ

Patrono: José Carlos Barbosa Moreira (in mem.). ISSN 1982-7636. pp. 229-260

www.redp.uerj.br

modo a propiciar "maiores possibilidades de assegurar um julgamento justo e leal em que

o imputado possa exercer efetivamente todos os seus direitos, especialmente o de se defender uma vez mais". 3 Contudo, a existência desses dois graus de cognição, somada à etapa de investigação preliminar, pode acarretar disfuncionalidade ao sistema processual penal se não houver a devida delimitação de suas respectivas funções. ${ }^{4}$ Por óbvio, não se sustenta aqui que há um distinto "devido processo" para cada etapa ou que ocorre um esvaziamento progressivo da presunção de inocência, por exemplo.

Contudo, a respectiva função de cada fase acarreta consequências para a leitura e a estruturação do seu regime procedimental. ${ }^{5}$ Desde já, vale ressaltar que, embora as funções específicas de cada fase sejam distintas, todas elas são partes integrantes do processo penal de um modo amplo. Assim, as finalidades específicas das fases procedimentais que o integram devem se guiar e se inserir nessa lógica, respeitando os seus princípios e reflexos.

A primeira fase da persecução penal, embora não obrigatória, é a de investigação preliminar (1). Em termos estritos, ela não é considerada processual, mas antecedente e preparatória, ${ }^{6}$ podendo ocorrer em diversas formas, como inquérito policial, inquérito civil público, investigação direta pelo Ministério Público, CPI, etc. ${ }^{7}$ Segundo Mendes de Almeida, "se a instrução definitiva prova ou não prova que há crime ou contravenção, a instrução preliminar prova ou não prova que há base para a acusação". ${ }^{8}$

\footnotetext{
${ }^{3}$ PASTOR, Daniel R. La nueva imagen de la casación penal. Evolución histórica y futuro de la dogmática de la impugnación en el derecho procesal penal. Buenos Aires: Ad-Hoc, 2001. p. 185 (tradução livre).

${ }^{4}$ BADARÓ, Gustavo Henrique. Manual dos Recursos Penais. São Paulo: RT, 2016. p. 56-58.

${ }^{5}$ Em relação à configuração da investigação preliminar diante do processo penal de modo amplo, Lopes Jr. e Gloeckner afirmam: "O processo penal tem como fundamento de sua existência a instrumentalidade constitucional, e esse também será o ponto de partida para justificar a investigação preliminar. Ela não pode afastar-se dos fundamentos do instrumento-maior ao qual presta serviço. Entretanto, dentro desse fim de instrumento de garantia, cabe questionar com mais especificidade o que pretende garantir a investigação preliminar." (LOPES JR., Aury; GLOECKNER, Ricardo J. Investigação Preliminar no Processo Penal. $6^{\mathrm{a}}$ ed. São Paulo: Saraiva, 2014. p. 99).

${ }^{6}$ FERNANDES, Antonio Scarance. Teoria Geral do Procedimento e O Procedimento no Processo Penal. São Paulo: RT, 2005. p. 35

${ }^{7}$ BADARÓ, Gustavo Henrique. Processo Penal. $2^{\text {a }}$ ed. Rio de Janeiro: Elsevier, 2014. p. 65.

${ }^{8}$ ALMEIDA, Joaquim C. M. A contrariedade na instrução criminal. São Paulo: [s.n.], 1937. p. 12. Deve-se ressaltar que "instrução preliminar" se refere à investigação preliminar, enquanto "instrução definitiva", ao juízo efetivamente processual. Além disso, em termos estritos, o que se produz na investigação preliminar, em regra, são elementos informativos, e não provas, as quais devem ser realizadas na fase processual, com respeito à oralidade e ao contraditório (sobre isso, ver: LOPES JR., Aury; GLOECKNER, Ricardo J. Investigação Preliminar no Processo Penal. 6a ed. São Paulo: Saraiva, 2014. p. 204-211). Marta Saad, contudo, aponta que os elementos produzidos no inquérito podem, além de informar, também servir ao convencimento do julgador para as decisões de admissibilidade da acusação ou eventuais medidas cautelares (SAAD, Marta. O direito de defesa no inquérito policial. São Paulo: RT, 2004. p. 160-161).
} 
Revista Eletrônica de Direito Processual - REDP.

Rio de Janeiro. Ano 12. Volume 19. Número 2. Maio a Agosto de 2018

Periódico Quadrimestral da Pós-Graduação Stricto Sensu em Direito Processual da UERJ

Patrono: José Carlos Barbosa Moreira (in mem.). ISSN 1982-7636. pp. 229-260

www.redp.uerj.br

Conforme Scarance Fernandes, trata-se de "expressão concreta de uma importante garantia, a de se evitar que alguém seja acusado sem estar verificada a existência de indícios razoáveis apontando-o como autor de um ilícito penal". 9 Certamente, a investigação preliminar também cumpre outras finalidades, que integram pontos fundamentais para sua estruturação teórica, como obter elementos no local do crime que podem originar provas futuramente, ou seja, assegurar a produção de eventuais provas irrepetíveis, além de propiciar elementos para eventuais decisões judiciais em sede cautelar. ${ }^{10}$ Diante disso, afirma-se que "a finalidade do inquérito policial é a apuração da existência da infração e a sua respectiva autoria (CPP arts. $4^{\circ}$ e 12), fornecendo elementos para que o Ministério Público - ou querelante - forme a opnio delicti e, em caso positivo, dê o embasamento probatório suficiente para que a ação penal tenha justa causa". ${ }^{11}$

Contudo, em termos gerais, pensa-se que o fundamento da investigação preliminar é evitar acusações ilegítimas e a colocação de um indivíduo na posição de réu em um processo penal sem embasamento suficiente. Se o seu objetivo fosse exclusivamente obter elementos probatórios, tornar-se-ia desnecessária, tendo em vista que isso poderia, teoricamente, ser realizado diretamente na fase processual, economizando tempo da persecução penal. Assim, conclui-se com Lopes Jr. e Gloeckner, que "a função de evitar acusações infundadas é o principal fundamento da investigação preliminar, pois, em realidade, evitar acusações infundadas significa esclarecer o fato oculto". ${ }^{12}$

A partir de tal premissa, sustenta-se que a investigação preliminar deve ser submetida a limitações cognitivas, em razão de sua instrumentalidade em relação ao processo penal. ${ }^{13}$ Afirma-se que "a instrução preliminar não deve ser normativamente uma cognição plena, profunda e completa sobre a existência do delito, pois esse é o objetivo da fase processual e da instrução definitiva". ${ }^{14}$ Considerando que a sua função é evitar acusações ilegítimas por meio da verificação dos fatos para propiciar elementos à decisão sobre o exercício do poder de acusar, não há motivo para se prosseguir com uma

\footnotetext{
${ }^{9}$ FERNANDES, Antonio Scarance. Teoria Geral do Procedimento e O Procedimento no Processo Penal. São Paulo: RT, 2005. p. 75.

${ }^{10}$ SAAD, Marta. O direito de defesa no inquérito policial. São Paulo: RT, 2004. p. 147-153.

${ }^{11}$ BADARÓ, Gustavo Henrique. Processo Penal. $2^{\text {a }}$ ed. Rio de Janeiro: Elsevier, 2014. p. 66.

${ }^{12}$ LOPES JR., Aury; GLOECKNER, Ricardo J. Investigação Preliminar no Processo Penal. $6^{\mathrm{a}}$ ed. São Paulo: Saraiva, 2014. p. 107-108.

${ }^{13}$ MACHADO, André Augusto Mendes. Investigação criminal defensiva. São Paulo: RT, 2010. p. 56-58.

${ }^{14}$ LOPES JR., Aury; GLOECKNER, Ricardo J. Investigação Preliminar no Processo Penal. $6^{\mathrm{a}}$ ed. São Paulo: Saraiva, 2014. p. 176.
} 
Revista Eletrônica de Direito Processual - REDP.

Rio de Janeiro. Ano 12. Volume 19. Número 2. Maio a Agosto de 2018

Periódico Quadrimestral da Pós-Graduação Stricto Sensu em Direito Processual da UERJ

Patrono: José Carlos Barbosa Moreira (in mem.). ISSN 1982-7636. pp. 229-260

www.redp.uerj.br

investigação preliminar se já há suficiência para a acusação ou para determinar um pedido de arquivamento. ${ }^{15}$

Percebe-se, desde já, que a estruturação dogmática do sistema processual penal deve considerar as suas essência e função gerais, mas cada etapa possui características específicas, que determinam sua finalidade e a construção do regime procedimental respectivo. Desse modo, há, por exemplo, diferenças cognitivas, que impõem distintas amplitudes na reconstrução histórica dos fatos, já que posição diversa acarretaria a distorção das etapas ou a sua sobreposição indevida. Nesse sentido, segundo Lopes Jr. e Gloeckner, "uma fase pré-processual plenária não representa mais do que uma molesta duplicidade ou, ainda pior, desvirtua completamente a fase processual, transformando-se na alma do processo". ${ }^{16}$

Em relação à aplicabilidade dos princípios reitores do processo penal também à etapa preliminar, há intensa discussão. Embora a doutrina clássica relativize e esvazie a incidência do direito de defesa e do contraditório nessa fase investigativa, há forte consolidação de posição que assegura o respeito desses elementos também em tal sede, ainda que considerando as suas limitações diante da função específica desempenhada na persecução penal. ${ }^{17}$ Afirma-se, por exemplo, que há incidência do contraditório na etapa investigatória, mas não em sua plenitude, já que, em razão da finalidade e das características da fase pré-processual, restringe-se sua efetividade, assegurando-se a informação ao réu, mas não uma total possibilidade de reação, participação e influência. ${ }^{18}$

\footnotetext{
15 "Entretanto, não tem sentido, depois de o inquérito policial já ter obtido elementos de informação suficientes para que o Ministério Público ou o querelante possa oferecer a denúncia ou queixa, retardar a propositura da ação penal em razão da realização de investigações inúteis, mormente porque não poderão servir de base para a formação do convencimento judicial, que deverá apreciar a prova produzida em contraditório judicial (CPP, art. 155, caput)." (BADARÓ, Gustavo Henrique. Processo Penal. $2^{\mathrm{a}}$ ed. Rio de Janeiro: Elsevier, 2014. p. 66).

${ }^{16}$ LOPES JR., Aury; GLOECKNER, Ricardo J. Investigação Preliminar no Processo Penal. $6{ }^{\mathrm{a}}$ ed. São Paulo: Saraiva, 2014. p. 176.

${ }^{17}$ SAAD, Marta. O direito de defesa no inquérito policial. São Paulo: RT, 2004. p. 198-205; CHOUKR, Fauzi Hassan. Garantias constitucionais na investigação criminal. $2^{\mathrm{a}}$ ed. Rio de Janeiro: Lumen Juris, 2001. p. 124-132; TUCCI, Rogério Lauria. Direitos e garantias individuais no processo penal brasileiro. $4^{\text {a }}$ ed. São Paulo: RT, 2011. p. 303-304; VILARES, Fernanda R.; BEDIN, Guilherme A. C.; CASTRO, Pedro M. A. Investigação criminal: o Projeto de Código de Processo Penal e investigação defensiva. Revista Brasileira de Ciências Criminais, São Paulo, v. 22, n. 107, p. 309-336, mar./abr. 2014. p. 322.

${ }^{18}$ MACHADO, André A. M. Investigação criminal defensiva. São Paulo: RT, 2010. p. 111; LOPES JR., Aury; GLOECKNER, Ricardo J. Investigação Preliminar no Processo Penal. $6^{\mathrm{a}}$ ed. São Paulo: Saraiva, 2014. p. 468.
} 
Revista Eletrônica de Direito Processual - REDP.

Rio de Janeiro. Ano 12. Volume 19. Número 2. Maio a Agosto de 2018

Periódico Quadrimestral da Pós-Graduação Stricto Sensu em Direito Processual da UERJ

Patrono: José Carlos Barbosa Moreira (in mem.). ISSN 1982-7636. pp. 229-260

www.redp.uerj.br

Distinta, mas intrinsicamente ligada à investigação preliminar, ${ }^{19}$ a fase

intermediária (2) caracteriza-se como um juízo de viabilidade da acusação, em que se verificará a sua admissão ou rejeição para, somente se aceita, iniciar efetivamente o processo penal em termos estritos. ${ }^{20}$ Trata-se de um momento entre as etapas preliminar e processual, em que se deveria realizar uma audiência oral em contraditório para verificação da acusação, de modo a possibilitar o exercício do direito de defesa para evitar o colocação do imputado na posição de réu. ${ }^{21}$

A etapa intermediária é subvalorizada e indevidamente comprimida na justiça criminal brasileira. $^{22}$ Inexiste no CPP atual uma real fase intermediária, pois no procedimento ordinário ela acaba reduzida somente à decisão do magistrado de receber ou rejeitar a denúncia sem a realização de uma audiência ou, em regra, de defesa prévia pelo imputado. ${ }^{23}$ Além disso, a jurisprudência majoritária agrava esse problema, esvaziando até mesmo a decisão sobre a admissibilidade da acusação ao afirmar que ela não precisa, necessariamente, ser motivada. ${ }^{24}$ A reforma legislativa de 2008 tentou inserir um momento de reação defensiva anterior ao recebimento da denúncia, ao menos de modo escrito, mas a redação original do projeto findou desvirtuada, consagrando a "mesóclise da discórdia", que manteve a sistemática anterior. ${ }^{25}$

De modo semelhante à investigação preliminar, na fase intermediária há uma limitação cognitiva, em razão de sua sumariedade, pois destina-se a realizar um juízo de probabilidade, que justifique a abertura do juízo oral, a partir de um standard probatório

19 “(...) o êxito da fase intermediária depende inteiramente da atividade preliminar, de modo que transferimos a ela o verdadeiro papel de evitar as acusações infundadas” (LOPES JR., Aury; GLOECKNER, Ricardo J. Investigação Preliminar no Processo Penal. 6 a ed. São Paulo: Saraiva, 2014. p. 107).

${ }^{20}$ ARMENTA DEU, Teresa. Juicio de acusación, imparcialidad del acusador y derecho de defensa. In: BACHMAIER WINTER, Lorena (coord.). Proceso penal y sistemas acusatorios. Madrid: Marcial Pons, 2008. p. 111; FERNANDES, Antonio Scarance. Teoria Geral do Procedimento e O Procedimento no Processo Penal. São Paulo: RT, 2005. p. 105. Em interpretação sistemática, Gustavo Badaró sustenta que o processo penal se inicia com o oferecimento da denúncia ou queixa, e não com o seu recebimento, ainda que não concretizada a relação processo entre julgador, acusador e réu (BADARÓ, Gustavo Henrique. Processo Penal. $2^{\text {a }}$ ed. Rio de Janeiro: Elsevier, 2014. p. 422).

${ }^{21}$ LOPES JR., Aury; GLOECKNER, Ricardo J. Investigação Preliminar no Processo Penal. $6^{\mathrm{a}}$ ed. São Paulo: Saraiva, 2014. p. 265.

${ }^{22}$ MOURA, Maria Thereza de Assis. Justa causa para a ação penal: doutrina e jurisprudência. São Paulo: RT, 2001. p. 235-237.

${ }^{23}$ FERNANDES, Antonio Scarance. Reação defensiva à imputação. São Paulo: RT, 2002. p. 162-164.

${ }^{24}$ LOPES JR., Aury; GLOECKNER, Ricardo J. Investigação Preliminar no Processo Penal. $6^{\mathrm{a}}$ ed. São Paulo: Saraiva, 2014. p. 108-109.

${ }^{25}$ LOPES JR., Aury. Direito processual penal. $9^{\text {a }}$ ed. São Paulo: Saraiva, 2012. p. 927-932; BADARÓ, Gustavo Henrique. Processo Penal. $2^{\text {a }}$ ed. Rio de Janeiro: Elsevier, 2014. p. 422-424. 
Revista Eletrônica de Direito Processual - REDP.

Rio de Janeiro. Ano 12. Volume 19. Número 2. Maio a Agosto de 2018

Periódico Quadrimestral da Pós-Graduação Stricto Sensu em Direito Processual da UERJ

Patrono: José Carlos Barbosa Moreira (in mem.). ISSN 1982-7636. pp. 229-260

www.redp.uerj.br

inferior àquele necessário para a condenação ao final do processo. ${ }^{26}$ Não há que se realizar uma reconstrução total e profunda dos fatos, mas exclusivamente o suficiente para tal julgamento de admissibilidade ou rejeição da acusação.

Por outro lado, em relação à efetivação dos direitos e garantias fundamentais, caracteriza-se uma expansão das possibilidades de sua incidência, tendo em vista que a fase intermediária se coloca no regime amplo da persecução penal exatamente para "oxigenar aquela fase nitidamente inquisitorial", que costuma ocorrer na investigação preliminar. ${ }^{27}$ Almeja-se permitir uma reação defensiva concreta à denúncia/queixa, com respeito ao contraditório em uma audiência oral e pública, o que, segundo Assis Moura, "contribuiria para impedir a formulação de imputações precipitadas e temerárias e diminuiria, via de consequência, a impetração de habeas corpus, visando ao trancamento da ação penal por falta de justa causa". ${ }^{28}$

A fase intermediária também é determinante para a consolidação de um nítida separação entre a investigação preliminar e a etapa processual, de modo a assegurar o que pode se definir como elemento fundamental de um sistema acusatório. ${ }^{29}$ Assim, conforme posição consolidada na doutrina há muito, impõe-se a exclusão física dos atos investigativos nos autos que formarão o processo. ${ }^{30} \mathrm{O}$ juízo de admissibilidade da acusação ainda pode ter a finalidade de verificar a legitimidade de eventual ingresso processual de elementos informativos produzidos na investigação, por exemplo, em casos de irrepetibilidade. Além disso, tal momento tem o potencial de propiciar um controle sobre eventuais ilicitudes probatórias, protegendo o processo de posteriores nulidades.

Admitida a acusação, ingressa-se na fase processual da persecução comumente denominada de juízo oral (3). Trata-se do estágio em que, por excelência, deve ocorrer a reconstrução histórica dos fatos, a partir de provas requeridas pelas partes e produzidas em

\footnotetext{
${ }^{26}$ LOPES JR., Aury; GLOECKNER, Ricardo J. Investigação Preliminar no Processo Penal. $6^{\mathrm{a}}$ ed. São Paulo: Saraiva, 2014. p. 267.

${ }^{27}$ Ibidem, p. 268.

${ }^{28}$ MOURA, Maria Thereza de Assis. Justa causa para a ação penal: doutrina e jurisprudência. São Paulo: RT, 2001. p. 237.

${ }^{29}$ ILLUMINATI, Giulio. El sistema acusatorio en Italia. In: BACHMAIER WINTER, Lorena (coord.). Proceso penal y sistemas acusatorios. Madrid: Marcial Pons, 2008. p. 153. Sobre isso: ANDRÉS IBÁÑEZ, Perfecto. Prueba y convicción judicial en el proceso penal. Buenos Aires: Hammurabi, 2009. p. 129.

${ }^{30}$ FERNANDES, Antonio Scarance. Teoria Geral do Procedimento e O Procedimento no Processo Penal. São Paulo: RT, 2005. p. 165-166; GOMES, Décio Luiz Alonso. Prova e imediação no processo penal. Salvador: Juspodivm, 2016. p. 131; LOPES JR., Aury; GLOECKNER, Ricardo J. Investigação Preliminar no Processo Penal. $6^{\text {a }}$ ed. São Paulo: Saraiva, 2014. p. 328-332.
} 
Revista Eletrônica de Direito Processual - REDP.

Rio de Janeiro. Ano 12. Volume 19. Número 2. Maio a Agosto de 2018

Periódico Quadrimestral da Pós-Graduação Stricto Sensu em Direito Processual da UERJ

Patrono: José Carlos Barbosa Moreira (in mem.). ISSN 1982-7636. pp. 229-260

www.redp.uerj.br

uma audiência oral, com respeito ao contraditório e à ampla defesa, objetivando a verificação da acusação imputada e admitida na fase intermediária. Diante da importância dessa etapa da persecução penal, ${ }^{31}$ a doutrina afirma que todo o sistema processual deve ser estruturado mirando a sua concretização e efetivação, o que tem sido denominado de "centralidade do juízo oral". 32

Pensa-se que a oralidade deve ser uma premissa básica para a estruturação do regime procedimental do processo penal. ${ }^{33}$ Conforme Alberto Binder, "sem juízo oral e público não há um sistema de justiça penal republicano, de base constitucional e fundado nos pactos internacionais de direitos humanos". ${ }^{34} \mathrm{O}$ modelo oral acarreta a centralidade da audiência no desenvolvimento do processo e na tomada da decisão. ${ }^{35}$ Ou seja, a apresentação dos pedidos e argumentos das partes, a produção da prova e o julgamento devem ocorrer em uma audiência pública, pautada pela oralidade e com a possibilidade de um efetivo debate entre os sujeitos processuais. Isso potencializa o controle sobre a decisão jurisdicional, limitando o subjetivismo, ${ }^{36}$ ampliando o impacto dos elementos produzidos e

31 Scarance Fernandes afirma que a tendência europeia das reformas na justiça criminal se pauta pela valorização da fase dos debates e julgamento (FERNANDES, Antonio Scarance. Teoria Geral do Procedimento e O Procedimento no Processo Penal. São Paulo: RT, 2005. p. 14). Assim também em relação às reformas latinas: RIEGO, Cristian. Los regímenes recursivos en los sistemas procesales penales acusatorios en las Américas: aspectos generales. In: ANUARIO de derecho penal 2010-2011. Buenos Aires: Ad-Hoc, 2012. p. 411.

32 DUCE, Mauricio; RIEGO, Cristián. Proceso Penal. Santiago: Editorial Juridica de Chile, 2011. p. 373374; RIEGO, Cristian. Los regímenes recursivos en los sistemas procesales penales acusatorios en las Américas: aspectos generales. In: ANUARIO de derecho penal 2010-2011. Buenos Aires: Ad-Hoc, 2012. p. 412; BINDER, Alberto M. La implementación de la nueva justicia penal adversarial. Buenos Aires: AdHoc, 2012. p. 32; GONZÁLEZ POSTIGO, Leonel. La oralidad en la etapa recursiva del proceso penal chileno. Las audiencias ante la Corte de Apelaciones de Santiago. Revista Derecho Penal, ano III, n. 07, p. 333-374, mai. 2014. p. 333; BELLINO, Silvia. La rinnovazione dell'instruttoria dibattimentale nel rito ordinario. In: IANDOLO, Lucia (org.). La prova nel giudizio di appello. Torino: Giappichielli, 2014. p. 76; DUCE, Mauricio; MARÍN, Felipe; RIEGO, Cristián. Reforma a los procesos civiles orales: consideraciones desde el debido proceso y calidad de la información. In: CABEZÓN, Andrea. ARANEDA, Sandra. (ed.). Justicia Civil: perspectivas para una reforma en América Latina. Santiago: CEJA, 2008. p. 35.

${ }^{33}$ CHINNICI, Daniela. L'Immediatezza nel Processo Penale. Milano: Giuffrè, 2005. p. 4.

${ }^{34}$ BINDER, Alberto M. La implementación de la nueva justicia penal adversarial. Buenos Aires: Ad-Hoc, 2012. p. 31 (tradução livre).

${ }^{35}$ CHIOVENDA, Giuseppe. A oralidade e a prova. Revista Forense, v. 74, p. 232-248, mai. 1939. p. 234. Sobre isso: BINDER, Alberto M. La implementación de la nueva justicia penal adversarial. Buenos Aires: Ad-Hoc, 2012. p. 172; DUCE, Mauricio; MARÍN, Felipe; RIEGO, Cristián. Reforma a los procesos civiles orales: consideraciones desde el debido proceso y calidad de la información. In: CABEZÓN, Andrea. ARANEDA, Sandra. (ed.). Justicia Civil: perspectivas para una reforma en América Latina. Santiago: CEJA, 2008. p. 29.

${ }^{36}$ MARINHO MARQUES, Leonardo Augusto. O princípio da oralidade e a descentralização da informação relevante no processo penal. Revista de Estudos Criminais, Porto Alegre, v. 10. n. 46, p. 157-170, jul./set. 2012. p. 168; CHINNICI, Daniela. L'Immediatezza nel Processo Penale. Milano: Giuffrè, 2005. p. 22-26. 
Revista Eletrônica de Direito Processual - REDP.

Rio de Janeiro. Ano 12. Volume 19. Número 2. Maio a Agosto de 2018

Periódico Quadrimestral da Pós-Graduação Stricto Sensu em Direito Processual da UERJ

Patrono: José Carlos Barbosa Moreira (in mem.). ISSN 1982-7636. pp. 229-260

www.redp.uerj.br

afastando da formação da convicção do magistrado os conhecimentos alheios ao processo. $^{37}$

Segundo Alberto Binder, é na fase do juízo oral que todos os direitos e garantias devem se concretizar plenamente, o que acarreta reflexos para as demais etapas da persecução, pois "durante toda a preparação do caso e durante o controle que se realiza nas impugnações, o juiz e as partes devem respeitar esses princípios". ${ }^{38}$ Desse modo, conforme o referido autor, todas as fases e institutos "adquirem seu fundamento e sentido em relação ao juízo oral", de modo que "são elementos que existem para preparar o juízo ou para o seu desenvolvimento ou para assegurar o seu controle". ${ }^{39}$

Por fim, a fase recursal (4), especialmente o juízo de segundo grau sobre a sentença, determina-se para realizar um controle ${ }^{40}$ sobre a suficiência e a legalidade da decisão judicial que rompe a presunção de inocência e supera a dúvida razoável. Contudo, vale ressaltar que o argumento de que a função do juízo recursal é controlar a decisão de primeiro grau não reduz de qualquer modo a necessidade de atenção aos princípios básicos do processo penal, visto que se impõe a conformação de um procedimento que propicie efetiva possibilidade de exercício do direito de defesa em contraditório, de modo que "as bases para que se efetue uma 'prova de resistência' da justiça da decisão devem ser iguais àquelas utilizadas para a cognição em primeiro grau". ${ }^{41}$

Diante da premissa estruturante do sistema processual a partir da centralidade do juízo oral, afirma-se que o modelo recursal precisa ser compatível com essa construção,

37 GONZÁLEZ POSTIGO, Leonel. La oralidad en la etapa recursiva del proceso penal chileno. Las audiencias ante la Corte de Apelaciones de Santiago. Revista Derecho Penal, ano III, n. 07, p. 333-374, mai. 2014. p. 368-370. Afirmando que a oralidade obriga o contato do juiz com os argumentos das partes: MORATO, Francisco. A oralidade. Revista Forense, Rio de Janeiro, vol. 74, fasc. 418, p. 141-148, abr. 1938. p. 146.

${ }^{38}$ BINDER, Alberto M. La implementación de la nueva justicia penal adversarial. Buenos Aires: Ad-Hoc, 2012. p. 172 (tradução livre).

${ }^{39}$ Ibidem, p. 230 (tradução livre). Assim também: DUCE, Mauricio; MARÍN, Felipe; RIEGO, Cristián. Reforma a los procesos civiles orales: consideraciones desde el debido proceso y calidad de la información. In: CABEZÓN, Andrea. ARANEDA, Sandra. (ed.). Justicia Civil: perspectivas para una reforma en América Latina. Santiago: CEJA, 2008. p. 63.

${ }^{40}$ Afirma-se que doutrina majoritária ressalta a função de controle do juízo recursal: ALCÁCER GUIRAO, Rafael. El Derecho a una Segunda Instancia con Todas las Garantías. Valencia: Tirant lo Blanch, 2013. p. 91; CRUZ, Rogério S. M. Garantias Processuais nos Recursos Criminais. $2^{\mathrm{a}}$ ed. São Paulo: Atlas, 2013. p. 18; DEL POZZO, Carlo Umberto. L'Appello nel processo penale. Torino: UTET, 1957. p. 5; MASSA, Michele. Contributo allo studio dell'appello nel processo penale. Milano: Giuffrè, 1969. p. 57.

${ }^{41}$ CHINNICI, Daniela. Giudizio Penale di Seconda Istanza e Giusto Processo. $2^{\mathrm{a}}$ ed. Torino: Giappichelli, 2009. p. 254 (tradução livre). 
Revista Eletrônica de Direito Processual - REDP.

Rio de Janeiro. Ano 12. Volume 19. Número 2. Maio a Agosto de 2018

Periódico Quadrimestral da Pós-Graduação Stricto Sensu em Direito Processual da UERJ

Patrono: José Carlos Barbosa Moreira (in mem.). ISSN 1982-7636. pp. 229-260

www.redp.uerj.br

sob pena de total esvaziamento do primeiro grau. ${ }^{42}$ Conforme Duce e Riego, "um modelo

de recursos que pretenda ser consistente com essas garantias deve, em primeiro lugar, se constituir a partir do juízo oral como elemento fundamental do sistema, cuja integridade e centralidade deve ser protegida". ${ }^{43}$

Contudo, tal afirmação deve ser analisada com cautela. Afirmar que não se pode ter certeza de que o juízo recursal efetivamente aporte maior justiça e segurança à persecução penal, tendo em vista que os julgadores de segundo grau também podem errar, é desconsiderar a função essencial da etapa impugnativa. Por óbvio, os magistrados dos tribunais são falíveis, mas, partindo da estruturação do recurso como um controle sobre os motivos da sentença, há uma indiscutível potencialidade de verificação e, assim, um aprimoramento da resposta estatal. ${ }^{44}$ Segundo Lucas Tassara, "o caso que ingressa no Tribunal para que se revise a condenação do imputado não o faz nas mesmas condições que o que ingressa ao juízo oral para que se julgue o mérito da acusação". 45

A fase recursal possui uma vantagem cognitiva em relação ao juízo oral de primeiro grau: ele parte de algo, ${ }^{46}$ ou seja, a etapa de impugnação inicia-se em um momento posterior da persecução, em que já houve a delimitação da imputação realizada pela acusação e a sua concretização pela produção das provas, findando com a sentença

42 RIEGO, Cristian. Los regímenes recursivos en los sistemas procesales penales acusatorios en las Américas: aspectos generales. In: ANUARIO de derecho penal 2010-2011. Buenos Aires: Ad-Hoc, 2012. p. 420; FUENTES MAUREIRA, Claudio. Derecho a recurso y el estándar fijado en el fallo Herrera Ulloa: una lectura hacia su compatibilidad con los sistemas procesales penales acusatorios. Revista CEJIL, ano IV, n. 05, p. 74-82, dez. 2009. p. 75.

${ }^{43}$ DUCE, Mauricio; RIEGO, Cristián. Proceso Penal. Santiago: Editorial Juridica de Chile, 2011. p. 505 (tradução livre).

${ }^{44}$ Sobre isso: LARA LÓPEZ, Antonio Maria. El recurso de apelación y la segunda instancia penal. Cizur Menor: Aranzadi, 2014. p. 122.

${ }^{45}$ TASSARA, Lucas. ¿Hasta donde llega el control de una sentencia? In: PASTOR, Daniel (dir.); GUZMÁN, Nicolás (coord.). Problemas actuales del Derecho Procesal Penal. Buenos Aires: Ad Hoc, 2012. p. 739 (tradução livre).

46 YÁÑEZ VELASCO, Ricardo. Derecho al recurso en el proceso penal. Nociones fundamentales y teoría constitucional. Valencia: Tirant Lo Blanch, 2001. p. 93; ARANGÜENA FANEGO, Coral. La doble instancia en el proceso penal. Criminalia, n. 65, p. 03-42, jan./abr. 1999. p. 32. Conforme Gustavo Badaró: "O que o recurso pode garantir é, apenas, a possibilidade de reduzir as chances de erro. Isso porque o segundo julgamento não será uma análise inicial que partirá do nada. Ao contrário, terá por base uma decisão anterior, que já será fruto de uma análise das questões de fato e de direito, cujo acerto ou equívoco será verificado pelo Tribunal" (BADARÓ, Gustavo Henrique. Manual dos Recursos Penais. São Paulo: RT, 2016. p. 39). Segundo Francesco Peroni, "o controle evoca uma operação de caráter acessório, necessariamente conexa a outro antecedente que se coloca como objeto de verificação" (PERONI, Francesco. L'istruzione debattimentale nel giudizio d'appello. Milão: CEDAM, 1995. p. 76) (tradução livre). 
Revista Eletrônica de Direito Processual - REDP.

Rio de Janeiro. Ano 12. Volume 19. Número 2. Maio a Agosto de 2018

Periódico Quadrimestral da Pós-Graduação Stricto Sensu em Direito Processual da UERJ

Patrono: José Carlos Barbosa Moreira (in mem.). ISSN 1982-7636. pp. 229-260

www.redp.uerj.br

condenatória. ${ }^{47}$ Ou seja, há um exercício progressivamente mais demarcado e, assim, efetivo da defesa ao longo do avence da persecução penal. Segundo Rosanna Fattibene, o magistrado de segundo grau possui mais chances de julgar melhor, "não porque é mais capaz ou competente, tampouco por ser infalível, mas pelo fato de intervir em um momento do complexo percurso processual que permite se aproveitar (ainda) dos erros do julgador precedente". 48

Portanto, o juízo recursal apresenta uma contribuição epistemológica ao permitir o exercício do direito de defesa de um modo mais concreto e direcionado, pois será possível impugnar direta e especificamente as bases que sustentam a decisão judicial condenatória. ${ }^{49}$ Aqui resta claro o reforço ao direito de defesa e à presunção de inocência propiciado por um efetivo direito ao recurso sobre a condenação. Como exposto por Arturo Capone, partindo de uma reconstrução histórica previamente realizada e com as delimitações apresentadas pelas partes em suas impugnações recursais, "o ponto de vista do julgador em segundo grau é de todo modo privilegiado". 50

Respeitando tais premissas, afirma-se que o procedimento recursal não pode ser concebido como um "novo juízo completo", que desconsidere os elementos produzidos em primeiro grau, pois assim se esvaziaria o seu próprio benefício ao regime geral do processo penal. ${ }^{51}$ Em relação às limitações cognitivas da esfera recursal, resta claro que há uma delimitação em relação à amplitude característica do juízo oral de primeiro grau. Conforme

47 RICHARD GONZÁLEZ, Manuel. La impugnación y revisión de la prueba mediante los recursos ordinarios y extraordinarios en el proceso penal. In: LLUCH, Xavier Abel; GONZÁLEZ, Manuel Richard (Dir.). Estudios sobre prueba penal: actos de investigación y medios de prueba en el proceso penal: diligencias de instrucción, entrada y registro, intervención de comunicaciones, valoración y revisión de la prueba en vía de recurso. Madrid: La Ley, 2013. p. 445

${ }^{48}$ FATTIBENE, Rosanna. Il doppio grado de giudizio tra garanzia dei diritti e organizzazione giudiziairia. Profili di comparazione. Torino: Giappichelli, 2010. p. 134 (tradução livre).

${ }^{49}$ Segundo Del Río Ferreti, trata-se de uma "posição epistemológica ao julgador ad quem substancialmente superior em relação ao juízo de primeira instância" (FERRETI, Carlos del Río. Estudio sobre el derecho al recurso en el proceso penal. Estudios Constitucionales, ano 10, n. 01, p. 245-288, 2012. p. 253) (tradução livre). Conforme Gustavo Herbel, "o direito ao recurso implica em garantir ao imputado o contraditório sobre os fundamentos de sua condenação perante um tribunal revisor" (HERBEL, Gustavo A. Derecho del imputado a revisar su condena. Motivación del fallo y derecho al recurso a través de las garantías constitucionales. Buenos Aires: Hammurabi, 2013. p. 47) (tradução livre).

${ }^{50}$ CAPONE, Arturo. Dopo Dan c. Moldavia. Per un processo di parti nell'appello penale. Rivista di Diritto Processuale, ano LXX, n. 4-5, p. 1007-1028, jul./out. 2015. p. 1027-1026 (tradução livre).

51 Nesse sentido: ALCÁCER GUIRAO, Rafael. El Derecho a una Segunda Instancia con Todas las Garantías. Valencia: Tirant lo Blanch, 2013. p. 72; CRUZ, Rogério S. M. Garantias Processuais nos Recursos Criminais. $2^{a}$ ed. São Paulo: Atlas, 2013. p. 24; HERBEL, Gustavo A. Derecho del imputado a revisar su condena. Motivación del fallo y derecho al recurso a través de las garantías constitucionales. Buenos Aires: Hammurabi, 2013. p. 52; PERONI, Francesco. L'istruzione debattimentale nel giudizio d'appello. Milão: CEDAM, 1995. p. 78. 
Revista Eletrônica de Direito Processual - REDP.

Rio de Janeiro. Ano 12. Volume 19. Número 2. Maio a Agosto de 2018

Periódico Quadrimestral da Pós-Graduação Stricto Sensu em Direito Processual da UERJ

Patrono: José Carlos Barbosa Moreira (in mem.). ISSN 1982-7636. pp. 229-260

www.redp.uerj.br

Daniel Pastor, enquanto "a primeira instância tem o seu objeto fixado pela acusação, a segunda tem seu objeto determinado pelo recurso". 52 Tais esferas devem ser concebidas a partir de uma leitura conjunta, ou seja, "não como componentes separados, mas complementares e partes de um mesmo sistema de produção das decisões judiciais". ${ }^{53}$ Portanto, utilizando a terminologia de Lopes Jr. e Gloeckner, se a investigação preliminar almeja formar um juízo de probabilidade e a fase processual do julgamento de primeira grau, um juízo de certeza; ${ }^{54}$ a esfera recursal pretende revisar essa certeza, de modo a reforçar a inexistência de qualquer violação de direitos ou dúvida razoável.

Assim, haverá impacto na amplitude cognitiva que caracteriza as fases da persecução penal, que Gustavo Badaró denomina de atividades "cognitivo-investigativa”, "cognitivo-probatória" e "cognitiva-revisional". 55 Tal sistemática, segundo Gustavo Herbel, desvela que dois juízos em graus distintos pressupõem que se adotem duas perspectivas diferentes: "a primeira, criativa: constrói a decisão racional com base no debate; a segunda, crítica: controla a racionalidade da decisão que autoriza o exercício da força contra uma pessoa (recurso sobre a condenação)". 56

\section{A proteção de direitos e garantias fundamentais nas fases da persecução penal: o exemplo do juízo de segundo grau}

A partir das considerações expostas, deve-se analisar a extensão dos direitos fundamentais nas distintas fases da persecução penal. Um dos principais pontos de tensão sobre tal temática diz respeito à necessidade de respeito às regras do devido processo penal também na esfera recursal. Diante disso, coloca-se fundamental problematização: os procedimentos das fases de juízo oral em primeiro grau e recursal em segundo grau devem ser regidos por idênticos princípios reitores? Considerando as distintas funções

\footnotetext{
${ }^{52}$ PASTOR, Daniel R. Los alcances del derecho del imputado a recurrir la sentencia. ¿La casación penal condenado? A propósito del caso 'Herrera Ulloa vs. Costa Rica' de la Corte Interamericana de Derechos Humanos. Revista de Ciencias Penales de Costa Rica, n. 23, p. 47-51, 2005. p. 50 (tradução livre).

${ }^{53}$ FUENTES MAUREIRA, Claudio. Derecho a recurso y el estándar fijado en el fallo Herrera Ulloa: una lectura hacia su compatibilidad con los sistemas procesales penales acusatorios. Revista CEJIL, ano IV, n. 05, p. 74-82, dez. 2009. p. 78 (tradução livre).

${ }^{54}$ LOPES JR., Aury; GLOECKNER, Ricardo J. Investigação Preliminar no Processo Penal. $6^{\text {a }}$ ed. São Paulo: Saraiva, 2014. p. 170-172.

${ }^{55}$ BADARÓ, Gustavo Henrique. Manual dos Recursos Penais. São Paulo: RT, 2016. p. 56-57.

${ }^{56}$ HERBEL, Gustavo A. Derecho del imputado a revisar su condena. Motivación del fallo y derecho al recurso a través de las garantías constitucionales. Buenos Aires: Hammurabi, 2013. p. 52 (tradução livre).
} 
Revista Eletrônica de Direito Processual - REDP.

Rio de Janeiro. Ano 12. Volume 19. Número 2. Maio a Agosto de 2018

Periódico Quadrimestral da Pós-Graduação Stricto Sensu em Direito Processual da UERJ

Patrono: José Carlos Barbosa Moreira (in mem.). ISSN 1982-7636. pp. 229-260

www.redp.uerj.br

desempenhadas por cada fase da persecução penal, as consequências de tais premissas são semelhantes?

Segundo Daniela Chinnici, há muito tempo a doutrina vinha assumindo como pacífico que não havia motivo para defender a extensão dos princípios fundamentais do juízo de primeiro grau ao procedimento recursal. ${ }^{57}$ Afirmava-se, por exemplo, que as fases apresentam lógicas que caracterizam sistemas totalmente distintos. ${ }^{58}$ A partir de tal visão, consolidou-se um lastro teórico que fomenta a estruturação normativa do procedimento impugnativo com desconsideração à oralidade e ao contraditório, além de embasar as práticas que corrompem ainda mais profundamente as normas do devido processo penal.

Contudo, a tese que sustenta a necessidade de superação dessa visão tem se fortalecido em âmbito internacional. Afirma-se que "se o juízo de apelação está julgando a partir das provas, e inegavelmente está, (...) ele não pode deixar de ser informado, pelo menos em termos de regra geral, pelas premissas do contraditório e da oralidadeimediação, com as partes em condições de confronto em paridade de armas". 59 Assim, os direitos e garantias previstos nas Constituições e nos diplomas convencionais de direitos humanos devem necessariamente impactar no regramento do juízo recursal. ${ }^{60}$

$\mathrm{Na}$ doutrina brasileira há incipientes manifestações sobre a temática. Por exemplo, Schietti Cruz afirma que a estruturação do processo penal com respeito aos direitos e garantias fundamentais, em uma perspectiva humanista, deve se realizar em todas as fases da persecução penal, de modo que no juízo recursal o imputado "merece a mesma proteção judiciária dispensada no primeiro grau, pois, afinal de contas, continua ele a ocupar o polo passivo da relação processual penal". ${ }^{61}$ Além disso, Lopes Jr. atesta que "a doutrina brasileira costuma tratar da principiologia aplicável aos recursos a partir das regras específicas, sem explicar que os princípios do processo penal também regem o sistema

${ }^{57}$ CHINNICI, Daniela. Giudizio Penale di Seconda Istanza e Giusto Processo. 2a ed. Torino: Giappichelli, 2009. p. 9.

${ }^{58}$ MASSA, Michele. Contributo allo studio dell'appello nel processo penale. Milano: Giuffrè, 1969. p. 18 e 59.

${ }^{59}$ CHINNICI, Daniela. Giudizio Penale di Seconda Istanza e Giusto Processo. $2^{\mathrm{a}}$ ed. Torino: Giappichelli, 2009. p. 49.

${ }^{60}$ GAITO, Alfredo. Verso una crisi evolutiva per il giudizio d'appello. Archivio Penale, n. 02, p. 1-7, 2012. p. 5; GAITO, Alfredo. Riformiamo le impugnazioni penali senza rinunciare al giusto processo. Archivio Penale, n. 02, p. 01-15, 2012. p. 5; YÁÑEZ VELASCO, Ricardo. Derecho al recurso en el proceso penal. Nociones fundamentales y teoría constitucional. Valencia: Tirant Lo Blanch, 2001. p. 389.

${ }^{61}$ CRUZ, Rogério S. M. Garantias Processuais nos Recursos Criminais. $2^{\mathrm{a}}$ ed. São Paulo: Atlas, 2013. p. 60. 
Revista Eletrônica de Direito Processual - REDP.

Rio de Janeiro. Ano 12. Volume 19. Número 2. Maio a Agosto de 2018

Periódico Quadrimestral da Pós-Graduação Stricto Sensu em Direito Processual da UERJ

Patrono: José Carlos Barbosa Moreira (in mem.). ISSN 1982-7636. pp. 229-260

www.redp.uerj.br

recursal, até porque não existe uma nova situação jurídico-processual, senão um desdobramento, um continum do processo originário". ${ }^{6}$

Nesse sentido já se posicionaram as cortes internacionais, ressaltando que a etapa recursal é parte integrante do processo penal e, ainda que configure uma nova fase da persecução, deve respeitar os seus princípios básicos para proteção de direitos humanos. ${ }^{63}$ Em 1986, no caso Ross vs. Reino Unido, o Tribunal Europeu de Direitos Humanos (TEDH) assentou: "quando a oportunidade de interpor um recurso em razão de uma acusação criminal é prevista no ordenamento interno, as garantias do artigo 6 (...) se aplicam ao juízo recursal, pois tais procedimentos formam parte do processo que decide o caso criminal em julgamento". ${ }^{64}$ Anteriormente, já havia afirmado, em Delcourt vs. Bélgica de 1970, que a criação de tribunais recursais nos ordenamentos internos dos países impõe o respeito aos direitos previstos no art. $6^{\circ}$ da Convenção Europeia de Direitos Humanos (CEDH) na sua configuração. ${ }^{65}$

Certamente, o caso mais famoso do TEDH sobre essa questão é Ekbatani vs. Suécia, de 1988. ${ }^{66}$ Conforme Alcácer Guirao, desde então o órgão europeu "vem reiterando que as garantias do devido processo (art. 6.1 CEDH) são exigíveis com plenitude na segunda instância". ${ }^{67}$ Tal posicionamento é repetido também em decisões mais recentes, como Hajiyev vs. Azerbaijão ${ }^{68}$ de 2006. Portanto, em resumo, o TEDH adota posição de que "o processo penal constitui um todo, e que a proteção que se impõe não termina com a sentença de primeiro grau, de modo que na apelação se deve assegurar ao imputado as garantias fundamentais do art. 6.1 da CEDH". 69

Em âmbito latino-americano, a Corte Interamericana de Direitos Humanos (CorteIDH) assentou visão semelhante no caso Castillo Petruzzi de 1999 e reiterou esse

${ }^{62}$ LOPES JR., Aury. Direito processual penal. $9^{\mathrm{a}}$ ed. São Paulo: Saraiva, 2012. p. 1166. Assim também: GOMES, Décio Luiz Alonso. Prova e imediação no processo penal. Salvador: Juspodivm, 2016. p. 193.

${ }^{63}$ LETELIER LOYOLA, Enrique. El Derecho Fundamental al Recurso en el Proceso Penal. Barcelona: Atelier, 2013. p. 119.

${ }^{64}$ MCBRIDE, Jeremy. Human rights and criminal procedure. The case law of the European Court of Human Rights. Strasbourg: Council of Europe Publishing, 2009. p. 307 (tradução livre).

${ }^{65}$ LETELIER LOYOLA, Enrique. El Derecho Fundamental al Recurso en el Proceso Penal. Barcelona: Atelier, 2013. p. 185. Decisão disponível em: <http://hudoc.echr.coe.int/eng?i=001-57467>. Acesso em: 21 nov. 2017.

${ }^{66}$ Disponível em: <http://echr.ketse.com/doc/10563.83-en-19880526/view/>. Acesso em: 21 nov. 2017.

${ }^{67}$ ALCÁCER GUIRAO, Rafael. El Derecho a una Segunda Instancia con Todas las Garantías. Valencia: Tirant lo Blanch, 2013. p. 33 (tradução livre).

${ }^{68}$ Disponível em: <http://freecases.eu/Doc/CourtAct/4536541>. Acesso em: 21 nov. 2017.

${ }^{69}$ TAPIA FERNÁNDEZ, Isabel. La implantación generalizada de la segunda instancia en el proceso penal. Presente y futuro. Madri: Civitas, 2011. p. 72 (tradução livre). 
Revista Eletrônica de Direito Processual - REDP.

Rio de Janeiro. Ano 12. Volume 19. Número 2. Maio a Agosto de 2018

Periódico Quadrimestral da Pós-Graduação Stricto Sensu em Direito Processual da UERJ

Patrono: José Carlos Barbosa Moreira (in mem.). ISSN 1982-7636. pp. 229-260

www.redp.uerj.br

precedente em diversos julgados posteriores. ${ }^{70}$ Conforme o órgão convencional, o direito

ao recurso sobre a condenação precisa ser efetivo, não sendo suficiente "a mera existência de um órgão de grau superior ao que julgou e condenou o acusado", de modo que, "para que haja uma verdadeira revisão da sentença, no sentido requerido pela Convenção, é preciso que o tribunal superior reúna as características jurisdicionais que legitimem o conhecimento do caso concreto". Assim, considerando que "o processo penal é um só durante suas várias fases, tanto à correspondente ao primeiro grau quanto aos demais", afirmou-se que "o conceito de juiz natural e de princípio do devido processo legal se aplicam nessas etapas e se projetam sobre os diversos graus jurisdicionais". ${ }^{71}$

Em julgados mais recentes, como os casos Mendoza vs. Argentina (2013) e Mohamed vs. Argentina (2012), que abordam diversas questões relacionadas ao direito ao recurso no processo penal, a CorteIDH assentou que "na regulamentação que os Estados determinem em seus respectivos regimes recursivos deve ser assegurado que o recurso contra a condenação respeite as garantias processuais mínimas que, conforme o artigo 8 da Convenção, se mostrem relevantes e necessárias para resolver as impugnações apresentadas pelo recorrentes, o que não acarreta que se deva realizar um novo juízo". 72

A partir dessas premissas, pensa-se que a conformação do juízo recursal aos ditames constitucionais e convencionais é uma imposição que deve ser buscada, o que se fundamenta, inicialmente, na necessidade de problematização do cenário atual pela doutrina, que pouco tem tratado da temática em âmbito brasileiro. Assim, a partir das premissas que serão desenvolvidas no próximo tópico, sustenta-se que todas as fases da persecução penal compartilham uma essência básica: ser um instrumento de limitação do poder punitivo, pois uma sanção penal somente pode ser imposta após a obtenção de uma condenação definitiva com total respeito às regras do devido processo penal.

\footnotetext{
${ }^{70}$ JUGO, Gabriela. El derecho de recurrir la sentencia penal condenatoria y los instrumentos internacionales de derechos humanos. In: GARCÍA, Luis M. (Coord.). Los derechos humanos en el proceso penal: función en el derecho interno, detención, prisión preventiva, recurso contra la sentencia de condena. Buenos Aires: Ábaco de Rodolfo Depalma, 2002. p. 282.

${ }^{71}$ Corte IDH. Caso Castillo Petruzzi y otros Vs. Perú. Julg. 30 de mayo de 1999. Serie C No. 52, § 161. Também nesse sentido, posterioremente: Corte IDH. Caso Herrera Ulloa Vs. Costa Rica. Julg. 2 de julho de 2004. Serie C No. 107, § 159; Corte IDH. Caso Lori Berenson Mejía Vs. Perú. Julg. 25 de novembro de 2004. Serie C No. 119, § 192; Corte IDH. Caso Radilla Pacheco Vs. México. Julg. 23 de novembro de 2009. Serie C No. 209, § 180; Corte IDH. Caso Vélez Loor Vs. Panamá. Julg. 23 de novembro de 2010 Serie C No. 218, § 179.

${ }^{72}$ Caso Mendoza v. Argentina, 2013, §246; Caso Mohamed vs. Argentina, 2012, §101.
} 
Revista Eletrônica de Direito Processual - REDP.

Rio de Janeiro. Ano 12. Volume 19. Número 2. Maio a Agosto de 2018

Periódico Quadrimestral da Pós-Graduação Stricto Sensu em Direito Processual da UERJ

Patrono: José Carlos Barbosa Moreira (in mem.). ISSN 1982-7636. pp. 229-260

www.redp.uerj.br

3. O fundamento e a função do processo penal como orientação para todas as fases da persecução penal

Assentada a visão geral sobre as fases da persecução penal e reconhecido o impacto da proteção de direito e garantias fundamentais em todas as suas etapas, deve-se buscar delimitar de modo concreto o elemento nuclear que orienta e fundamenta o processo penal. Trata-se de premissa essencial para a estruturação de uma dogmática processual penal.

Há muito afirma-se que o poder tende ao abuso e, portanto, precisa de freios constantes para sua contenção. ${ }^{73} \mathrm{E}$ tal característica assume perspectivas incomparáveis quando se trata do dispositivo mais intrusivo do âmbito de atuação estatal: o direito penal. Como apontado por Eugenio Zaffaroni, "a seletividade, a reprodução da violência, a criação de condições para maiores condutas lesivas, a corrupção institucionalizada, a concentração de poder, a verticalização social e a destruição das relações horizontais ou comunitárias não são características conjunturais, mas estruturais do exercício de poder de todos os sistemas penais". 74 Isso, por óbvio, se reflete no direito processual penal brasileiro, que é regido por um código de fortes inspirações autoritárias, ${ }^{75}$ atestando um abismo ideológico entre suas disposições e a normativa constitucional e convencional. ${ }^{76}$

Conforme a posição consolidada no estudo do direito processual, após a superação das fases praxista/sincretista e cientificista/conceitual de sua análise,${ }^{77}$ desponta a teoria da instrumentalidade do processo, que, além de ressaltar a conexão entre direito material e

\footnotetext{
73 “(...) trata-se de uma experiência eterna que todo homem que possui poder é levado a dele abusar; ele vai até onde encontra limites. Quem diria! Até a virtude precisa de limites." (MONTESQUIEU, Charles de Secondat. O espírito das leis. São Paulo: Martins Fontes, 1996. p. 166). Sobre isso: HERBEL, Gustavo A. Derecho del imputado a revisar su condena. Motivación del fallo y derecho al recurso a través de las garantías constitucionales. Buenos Aires: Hammurabi, 2013. p. 48.

${ }^{74}$ ZAFFARONI, Eugenio Raúl. Em busca das penas perdidas. A perda de legitimidade do sistema penal. Rio de Janeiro: Revan, 2014. p. 15. Assim também: PASTOR, Daniel. La ideología penal de ciertos pronunciamientos de los órganos del sistema interamericano de derechos humanos: ¿garantías para el imputado, para la víctima o para el aparato represivo del estado? In: AMBOS, Kai; MALARINO, Ezequiel; ELSNER, Gisela (editores). Sistema interamerica de protección de los derechos humanos y derecho penal internacional. Tomo II. Berlim: Konrad-Adenauer-Stiftung, 2011. p. 490.

75 Sobre isso, ver: MALAN, Diogo. Ideologia política de Francisco Campos: influência na legislação processual penal brasileira (1937-1941). In: PRADO, Geraldo; MALAN, Diogo (org.). Autoritarismo e Processo Penal Brasileiro. Rio de Janeiro: Lumen Juris, 2015. p. 01-85; AMARAL, Augusto Jobim do. Introdução à história das ideias do processo penal brasileiro. Revista História, ano 4, vol. 1, n. 1, p. 192 221, 2013. p. 194-200.

${ }^{76}$ BADARÓ, Gustavo Henrique. Manual dos Recursos Penais. São Paulo: RT, 2016. p. 68-69.

${ }^{77}$ JOBIM, Marco Félix. Cultura, escolas e fases metodológicas do processo. $3^{\text {a }}$ ed. Porto Alegre: Livraria do Advogado, 2016. p. 139-154.
} 
Revista Eletrônica de Direito Processual - REDP.

Rio de Janeiro. Ano 12. Volume 19. Número 2. Maio a Agosto de 2018

Periódico Quadrimestral da Pós-Graduação Stricto Sensu em Direito Processual da UERJ

Patrono: José Carlos Barbosa Moreira (in mem.). ISSN 1982-7636. pp. 229-260

www.redp.uerj.br

processual, $^{78}$ rompe as barreiras teóricas sobre os seus escopos jurídicos e ressalta sua vertente social e política, segundo estabelecido por Cândido Dinamarco. ${ }^{79}$ Afirma-se que “a pacificação é o escopo magno da jurisdição e, por consequência, de todo o sistema processual (uma vez que todo ele pode ser definido como a disciplina jurídica da jurisdição e seu exercício)". ${ }^{80}$ Afastando-se a ideia de um processo como fim em si mesmo, "a instrumentalidade enquanto metodologia processual significa que todo o saber/fazer processualista deve estar voltado para a efetividade do processo", superando formalismos em busca de resultados concretos na atuação do direito material e dos escopos extrajurídicos da jurisdição. ${ }^{81}$

Tal teoria assenta premissas que acarretam questionáveis consequências a partir de transplantes acríticos ao processo penal. ${ }^{82}$ Por exemplo, decorrência da primazia dos escopos não jurídicos, o princípio da instrumentalidade das formas, alimentado pela visão teleológica do processo que consolida o "aspecto negativo da instrumentalidade", $83 \mathrm{em}$ leituras exageradas, finda por supervalorizar a regra da necessidade de prejuízo para reconhecimento de nulidades processuais, ${ }^{84}$ o que, em interpretação corriqueira dos

\footnotetext{
78 “Falar em instrumentalidade do processo, pois, não é falar somente nas suas ligações com a lei material. O Estado é responsável pelo bem-estar da sociedade e dos indivíduos que a compõem: e, estando o bem-estar social turbado pela existência de conflitos entre as pessoas, ele se vale do sistema processual para, eliminando os conflitos, devolver à sociedade a paz desejada." (CINTRA, Antonio C. A.; GRINOVER, Ada P.; DINAMARCO, Cândido R. Teoria Geral do Processo. $24^{\mathrm{a}}$ ed. São Paulo: Malheiros, 2008. p. 47).

${ }^{79}$ DINAMARCO, Cândido Rangel. A instrumentalidade do processo. $15^{\mathrm{a}}$ ed. São Paulo: Malheiros, 2013. p. 182. Conforme Antônio Machado, "pode-se concluir que a ciência processual, no atual estágio da instrumentalidade, se caracteriza basicamente (a) pela concepção do processo como instrumento técnico de composição da lide e instrumento ético de participação política; (b) pela ideia de jurisdição como espaço de poder tendente à consecução de seus escopos sociais, políticos e jurídicos; (c) bem como pela noção de acesso à justiça enquanto método e fator legitimante tanto do saber quanto do fazer processuais" (MACHADO, Antônio Alberto. Teoria Geral do Processo Penal. São Paulo: Atlas, 2009. p. 91).

${ }^{80}$ CINTRA, Antonio C. A.; GRINOVER, Ada P.; DINAMARCO, Cândido R. Teoria Geral do Processo. $24^{\mathrm{a}}$ ed. São Paulo: Malheiros, 2008. p. 30.

${ }^{81}$ MACHADO, Antônio Alberto. Teoria Geral do Processo Penal. São Paulo: Atlas, 2009. p. 93. Sobre a instrumentalidade em uma proposta revista de teoria geral do processo: GRINOVER, Ada Pellegrini. Ensaio sobre a processualidade. Fundamentos para uma nova teoria geral do processo. Brasília: Gazeta, 2016. p. 13-14.

${ }^{82}$ BARROS, Flaviane de Magalhães. (Re)forma do Processo Penal. $2^{\text {a }}$ ed. Belo Horizonte: Del Rey, 2009. p. 11-14.

${ }^{83}$ DINAMARCO, Cândido Rangel. A instrumentalidade do processo. $15^{\mathrm{a}}$ ed. São Paulo: Malheiros, 2013. p. 316-318.

84 Sobre o princípio do prejuízo, ver: GRINOVER, Ada Pellegrini; GOMES FILHO, Antonio M.; FERnANDES, Antonio S. As Nulidades no Processo Penal. $7^{\mathrm{a}}$ ed. São Paulo: RT, 2001. p. 28-29; PASCHOAL, Jorge Coutinho. O prejuízo e as nulidades processuais penais. Um estudo à luz da jurisprudência do Supremo Tribunal Federal e do Superior Tribunal de Justiça. Rio de Janeiro: Lumen Juris, 2014. p. 302-343.
} 
Revista Eletrônica de Direito Processual - REDP.

Rio de Janeiro. Ano 12. Volume 19. Número 2. Maio a Agosto de 2018

Periódico Quadrimestral da Pós-Graduação Stricto Sensu em Direito Processual da UERJ

Patrono: José Carlos Barbosa Moreira (in mem.). ISSN 1982-7636. pp. 229-260

www.redp.uerj.br

tribunais brasileiros, inviabiliza quase integralmente a proteção das formas procedimentais em seu aspecto de garantia de direitos fundamentais. ${ }^{85}$

A crença na capacidade de o processo penal ser um meio de resolução de conflitos de tamanha complexidade ou de pacificação social por certo consolida um mito, ${ }^{86}$ que perfaz uma "ferida narcísica" 87 da dogmática processual penal. Com relação à esfera material, resta claro que o desvelamento das cifras ocultas de criminalidade findou por relevar que "não há mínima correspondência, no plano da eficácia, entre o processo de criminalização primária e o de criminalização secundária", ou seja, a pretensão de tratamento igualitária do direito penal como resposta ao cometimento de um delito se mostra ilusória na atuação prática do sistema criminal. ${ }^{88}$ Aqui também há uma conexão entre as funções do processo e do direito penal, especificamente com as teorias da pena. Além de amplamente questionadas na doutrina penal, ${ }^{89}$ as funções preventivas da punição carecem de qualquer comprovação empírica. ${ }^{90}$ Portanto, é primordial a adoção de uma racionalidade que tenha consciência de seus próprios limites. ${ }^{91}$

Por outro lado, uma primazia exacerbada da função de assegurar a atuação das normas substanciais acaba por esvaziar por completo a autonomia do processo e de suas categorias próprias. $^{92}$ Ao adentrar a lógica do sistema punitivo, tal argumentação

${ }^{85}$ GLOECKNER, Ricardo Jacobsen. Nulidades no Processo Penal. Introdução principiológica à teoria do ato processual irregular. Salvador: JusPodivm, 2013. p. 247-261 e 475-484; PAULA, Leonardo Costa de. As Nulidades no Processo Penal. Sua compreensão por meio da afirmação do direito como controle ao poder de punir. Curitiba: Juruá, 2013. p. 83-121.

${ }^{86}$ CASARA, Rubens R. R. Mitologia Processual Penal. São Paulo: Saraiva, 2015. p. 202.

${ }^{87}$ CARVALHO, Salo. Antimanual de criminologia. $3^{\mathrm{a}}$ ed. Rio de Janeiro: Lumen Juris, 2010. p. 91-110. Sobre isso, ver também: SAAVEDRA, Giovani Agostini; VASCONCELLOS, Vinicius G. Expansão do Direito Penal e Relativização dos Fundamentos do Direito Penal. Revista de Estudos Criminais, São Paulo, $n^{\circ} .42$, p. 123-142, jul./set. 2011. p. 138-141.

${ }^{88}$ Ibidem, p. 93. Como exemplo, ver a discussão sobre a viabilidade fática do princípio da obrigatoriedade no processo penal: CAPPARELLI, Bruna; VASCONCELLOS, Vinicius G. Notas sobre a perene crise do princípio da obrigatoriedade da ação penal no ordenamento italiano. Revista Eletronica de Direito Processual, Rio de Janeiro, ano 11, vol. 18, n. 1, p. 118-149, jan.-abr. 2017.

${ }^{89}$ Exemplificativamente: ALBRECHT, Peter-Alexis. Criminologia. Uma Fundamentação para o Direito Penal. Rio de Janeiro: Editora Lumen Juris, 2010. p. 86-90.

90 “(...) a crença na utilidade do processo penal na pacificação social não encontra suporte em pesquisas empíricas acerca dos efeitos da persecução penal no punido e na sociedade.” (CASARA, Rubens R. R. Mitologia Processual Penal. São Paulo: Saraiva, 2015. p. 197).

${ }^{91}$ DUCLERC, Elmir. Por uma teoria do processo penal. Florianópolis: Empório do Direito, 2015. p. 21.

92 "A natureza instrumental do direito processual impõe sejam seus institutos concebidos em conformidade com as necessidades do direito substancial. Em outras palavras, como o processo é meio, a eficácia do sistema processual será medida em função de sua utilidade para o ordenamento jurídico material e para a pacificação social. Não interessa, portanto, uma ciência processual conceitualmente perfeita, mas que não consiga atingir os resultados a que se propõe." (BEDAQUE, José Roberto dos Santos. Direito e Processo. Influencia do direito material sobre o processo. $6^{\mathrm{a}}$ ed. São Paulo: Malheiros, 2011. p. 23). 
Revista Eletrônica de Direito Processual - REDP.

Rio de Janeiro. Ano 12. Volume 19. Número 2. Maio a Agosto de 2018

Periódico Quadrimestral da Pós-Graduação Stricto Sensu em Direito Processual da UERJ

Patrono: José Carlos Barbosa Moreira (in mem.). ISSN 1982-7636. pp. 229-260

www.redp.uerj.br

possibilita propostas de preeminência dos interesses político-criminais, ${ }^{93}$

fundamentalmente percebidos como a tutela da segurança para defesa social, ${ }^{94}$ como a ideia de "funcionalização do processo penal". ${ }^{95}$ Por certo, trata-se de opção temerária, especialmente diante das já apontadas características invariavelmente patológicas do sistema penal, intensificadas pelo cenário de constante expansão do poder punitivo para controle social, ${ }^{96}$ reforçando a inerente lógica de reprodução de desigualdades e seletividade. ${ }^{97}$ Portanto, pode-se afirmar que o modelo de justiça penal contemporâneo está fundamentalmente pautado pela concepção de "emergência", 98 determinando-se como instrumento de governamentalidade. ${ }^{99}$ Ou seja, diante da realidade contraproducente e seletiva, o processo não pode ter outra função senão limitar o poder punitivo estatal para contenção de danos. ${ }^{100}$

Para esclarecer tais definições acerca da essência do processo penal, fundamento e função devem ser analisados como conceitos distintos. Conforme exposto por Faria Costa,

\footnotetext{
93 "Uma visão errônea de instrumentalidade pode fazer com que se pense o processo penal, ao invés de enquanto expediente de conformação das garantias fundamentais (constitucionais) de base, como mero fantoche a serviço de uma maior verticalização político-criminal" (DIVAN, Gabriel. Processo Penal $e$ Política Criminal: uma reconfiguração da justa causa para a ação penal. Porto Alegre: Elegantia Juris, 2015. p. 146-147). Ver também: DIVAN, Gabriel A. Crítica científica de "A colaboração premiada como instrumento de política criminal" - Um adendo sobre a necessária visão político-criminal do processo penal. Revista Brasileira de Direito Processual Penal, Porto Alegre, vol. 3, n. 1, p. 417-428, jan./abr. 2017.

${ }^{94}$ SANTOS, Bartira M. de Miranda. Defesa Social. Uma visão crítica. São Paulo: Estúdio, 2015. p. 90-106.

${ }^{95}$ FERNANDES, Fernando. O processo penal como instrumento de política criminal. Coimbra: Almedina, 2001. p. 73-77; DIAS, Jorge de Figueiredo. Acordos sobre a sentença em processo penal. O "fim" do Estado de Direito ou um novo "princípio"? Porto: Conselho Distrital do Porto, 2011. p. 37-39.

${ }^{96}$ GARLAND, David. Culture of Control. Chicago: The University of Chicago Press, 2001. p. 167-192; SILVA SÁNCHEZ, Jesús-María. La Expansión del Derecho penal. $3^{\text {a }}$ edição. Madrid: Edisofer, 2011. p. 189.

${ }^{97}$ BARATTA, Alessandro. Criminologia Crítica e Crítica do Direito Penal. Rio de Janeiro: Revan, 2002. p. 171-196; WACQUANT, Loïc. Punir os pobres. A nova gestão da miséria nos Estados Unidos. $3^{\mathrm{a}}$ ed. Rio de Janeiro: Revan, 2007. p. 25-75.

${ }^{98}$ CHOUKR, Fauzi Hassan. Processo Penal de Emergência. Rio de Janeiro: Lumen Juris, 2002. p. 01-09.

99 SIMON, Jonathan. Governing Through Crime. How the war on crime transformed american democracy and created a culture of fear. Oxford: Oxford University Press, 2007. p. 03-31; ROSA, Alexandre Morais da; AMARAL, Augusto Jobim do. Cultura da Punição. A ostentação do horror. Rio de Janeiro: Lumen Juris, 2014. p. 19-43.

100 “(...) o direito penal e processual penal resultam ainda necessários como alternativas à política, apresentando-se como tecnologia de minimização da violência e do arbítrio punitivo" (CARVALHO, Salo. Antimanual de criminologia. $3^{\mathrm{a}}$ ed. Rio de Janeiro: Lumen Juris, 2010. p. 152). Sobre a estruturação da teoria do delito em tais termos: ZAFFARONI, Eugenio Raúl. Em busca das penas perdidas. A perda de legitimidade do sistema penal. Rio de Janeiro: Revan, 2014. p. 245-246. Conforme Ricardo Gloeckner, "se o poder é tendente à expansão, cabe ao processo limitar tal poder punitivo, de molde a minimizar ao máximo os riscos de lesão aos direitos primordiais do acusado" (GLOECKNER, Ricardo Jacobsen. Nulidades no Processo Penal. Introdução principiológica à teoria do ato processual irregular. Salvador: JusPodivm, 2013. p. 30). Assim também: KHALED JR., Salah H. A busca da verdade no processo penal. Para além da ambição inquisitorial. São Paulo: Atlas, 2013. p. 362.
} 
Revista Eletrônica de Direito Processual - REDP.

Rio de Janeiro. Ano 12. Volume 19. Número 2. Maio a Agosto de 2018

Periódico Quadrimestral da Pós-Graduação Stricto Sensu em Direito Processual da UERJ

Patrono: José Carlos Barbosa Moreira (in mem.). ISSN 1982-7636. pp. 229-260

www.redp.uerj.br

o fundamento é o "porquê", a razão de ser de algo, enquanto a função (finalidade) diz

respeito ao "para quê". ${ }^{101}$ Assim, desenvolvendo tais premissas, Raquel Scalcon esclarece que existe uma relação de prejudicialidade entre tais conceitos: primeiro se analisa o fundamento para depois examinar as possíveis funções, que devem ser compatíveis com aquela premissa previamente estabelecida. ${ }^{102}$ Além disso, coloca-se uma estreita relação entre o fundamento e o sentido, de modo que este toca a essência do instituto, ao determinar o seu conteúdo estruturante. ${ }^{103}$

A partir de tal lastro teórico, pode-se afirmar que o fundamento do processo penal, sua razão de existir, é o reconhecimento de que, em um Estado democrático de direito, uma sanção penal (especialmente, prisão) somente pode ser imposta após a obtenção de uma condenação definitiva com total respeito às regras do devido processo penal. ${ }^{104} \mathrm{E}$, assim, ele adquire o sentido de ser um instrumento de limitação do poder punitivo ao condicionar a aplicação de uma sanção penal ao seu transcorrer e encerramento, em respeito às regras do devido processo. ${ }^{105} \mathrm{Ou}$ seja, o processo penal se fundamenta no princípio da necessidade (nulla poena sine iudicio), ${ }^{106}$ como caminho necessário para a

${ }^{101}$ FARIA COSTA, José Francisco de. Noções fundamentais de direito penal. $2^{\mathrm{a}}$ ed. Coimbra: Coimbra Editora, 2009. p. 17.

102 SCALCON, Raquel Lima. Ilícito e pena. Modelos opostos de fundamentação do direito penal contemporâneo. Rio de Janeiro: GZ Editora, 2013. p. 13.

103 CASTANHEIRA NEVES, Antonio. Entre o "legislador", a "sociedade" e o "juiz" ou entre "sistema", "função" e "problema" - os modelos actualmente alternativos de realização jurisdicional do direito. Boletim da Faculdade de Direito da Universidade de Coimbra, vol. LXXIV, p. 1-44, 1998. p. 2-4; SCALCON, Raquel Lima. Ilícito e pena. Modelos opostos de fundamentação do direito penal contemporâneo. Rio de Janeiro: GZ Editora, 2013. p. 12.

104 “(...) para que se possa impor uma pena não é suficiente que haja uma infração (delito ou falta), mas também é necessário que haja processo. A pena não é somente um efeito (jurídico) do delito, mas, por outro lado, é um efeito do processo" (GÓMEZ ORGANEJA, Emilio. Comentarios a la Ley de Enjuiciamiento Criminal. Tomo I. Barcelona: Bosch, 1951. p. 27) (tradução livre). Sobre isso: MONTERO AROCA, Juan. Proceso penal y libertad. Ensayo polémico sobre el nuevo proceso penal. Madrid: Thomson Civitas, 2008. p. 25-36 e 61-64.

${ }^{105}$ BINDER, Alberto M. La implementación de la nueva justicia penal adversarial. Buenos Aires: Ad-Hoc, 2012. p. 74; CASARA, Rubens R. R.; MELCHIOR, Antonio Pedro. Teoria do Processo Penal brasileiro. Dogmática e crítica: conceitos fundamentais. Vol. 1. Rio de Janeiro: Lumen Juris, 2013. p. 258. Em relação ao direito penal material, Raquel Scalcon afirma que o seu fundamento é o ilícito penal, essencialmente em sua vertente objetiva na verificação de uma ofensa a um bem jurídico penal, de modo que: “(...) o lugar de significado do Direito Penal reside em um fundamento, não em uma função. Se este o seu lugar, então um dos sentidos que lhe deve ser atribuído - mas não o único - é o de uma limitação ao poder do Estado nullum crimen sine iniuria. Nunca, portanto, o de uma expansão irrestrita, mesmo que supostamente realizada em nome dos mais relevantes fins." (SCALCON, Raquel Lima. Ilícito e pena. Modelos opostos de fundamentação do direito penal contemporâneo. Rio de Janeiro: GZ Editora, 2013. p. 152).

${ }^{106}$ GIACOMOLLI, Nereu José. O Devido Processo Penal. Abordagem conforme a Constituição Federal e o Pacto de São José da Costa Rica. São Paulo: Atlas, 2014. p. 401-406; LOPES JR., Aury. Direito Processual Penal. $9^{\text {a }}$ ed. São Paulo: Saraiva, 2012. p. 85-88; CASARA, Rubens R. R.; MELCHIOR, Antonio Pedro. Teoria do Processo Penal brasileiro. Dogmática e crítica: conceitos fundamentais. Vol. 1. 
Revista Eletrônica de Direito Processual - REDP.

Rio de Janeiro. Ano 12. Volume 19. Número 2. Maio a Agosto de 2018

Periódico Quadrimestral da Pós-Graduação Stricto Sensu em Direito Processual da UERJ

Patrono: José Carlos Barbosa Moreira (in mem.). ISSN 1982-7636. pp. 229-260

www.redp.uerj.br

concretização de uma sanção criminal, efetivando-se como limitação do poder punitivo

estatal. ${ }^{107}$ Trata-se de sentido compartilhado com os diplomas internacionais de proteção de direitos humanos, ${ }^{108}$ que consolida uma perene tensão entre legitimação e contenção do sistema punitivo. ${ }^{109}$

Percebe-se, portanto, que a instrumentalidade do processo em relação ao direito material se relaciona diretamente com o fundamento do processo penal, mas enfocada em sua relação de dependência recíproca, ou seja, autolimitação de poder. ${ }^{110}$ Se outra fosse a interpretação, "não haveria necessidade de colocar em movimento toda uma atividade complexa e custosa, cumprindo uma série de formas que certamente tendem a retardar o pronto castigo pelo delito". ${ }^{111}$ Assim, além da autonomia de suas categorias para estruturação de um sistema de limitação do poder, o processo penal também acarreta consequências ao direito material, pois se reflete em suas construções teóricas ao condicionar sua concretização. ${ }^{112}$

Rio de Janeiro: Lumen Juris, 2013. p. 134-136. Segundo Paolo Taormina, "o processo é necessário e indefectível, pois se instrumentaliza por meio da exigência absoluta do ordenamento de se concretizar, como síntese dos interesses da coletividade, os fins da pena; e porque tramitam resoluções da incerteza à certeza" (TAORMINA, Paolo. L’Essenzialità del Procedimento Penale. Napoli: Jovene, 1974. p. 83) (tradução livre).

107 "Tudo isso significa que (no plano do processo de tipo condenatório, pelo menos) a jurisdição deveria ser apresentada não exatamente como poder, mas como autêntico contra-poder, que tensiona com o poder punitivo, para limitá-lo, e essa é a única maneira possível de assegurar a efetividade do direito de defesa, conferindo-lhe a musculatura necessária para confrontar-se com a força do Estado-acusador" (DUCLERC, Elmir. Por uma teoria do processo penal. Florianópolis: Empório do Direito, 2015. p. 76).

${ }^{108}$ PASTOR, Daniel R. El llamado "impacto" de los tratados de derechos humanos en el derecho interno con especial referencia al derecho procesal penal. Cuadernos de Doctrina y Jurisprudencia Penal, Buenos Aires, ano 05, n. 09, p. 41-57, 1999. p. 44; RAMOS, André de Carvalho. Teoria Geral dos Direitos Humanos na Ordem Internacional. 4ª ed. São Paulo: Saraiva, 2014. p. 144.

109 "O problema é idêntico em matéria penal: as garantias referidas ao poder penal do Estado, embora pretendam colocar limites precisos a esse poder, também lhe legitimam, pois reconhecem ele como seu pressuposto, como substrato ao qual essas garantias se referem. O problema é, em uma determinada época ou para um Estado concreto, qual das duas visões alcança maior sustentação e aplicação prática: a que legitima o poder estatal ou aquela que o limita." (MAIER, Julio B. J. Derecho Procesal Penal. Tomo I. $2^{\text {a }}$ ed. Buenos Aires: Del Puerto, 2004. p. 475) (tradução livre).

110 “A 'interdependência' (notória) entre o direito material e o direito processual (que nessa quadra histórica pode ser discutida sem nenhum receio de volta à concretude da ação e à confusão de categorias dogmática), faz com que se perceba o processo como (instrumentalmente) destinado a uma tutela constitucionalmente qualificada do direito material." (DIVAN, Gabriel. Processo Penal e Política Criminal: uma reconfiguração da justa causa para a ação penal. Porto Alegre: Elegantia Juris, 2015. p. 137).

${ }^{111}$ LETELIER LOYOLA, Enrique. El Derecho Fundamental al Recurso en el Proceso Penal. Barcelona: Atelier, 2013. p. 23 (tradução livre).

112 MAIER, Julio B. J. Derecho Procesal Penal. Tomo I. $2^{\text {a }}$ ed. Buenos Aires: Del Puerto, 2004. p. 486-489; IACOVIELLO, Francesco M. La motivazione dela sentenza penale e il suo controllo in cassazione. Milano: Giuffrè, 1997. p. 48. 
Revista Eletrônica de Direito Processual - REDP.

Rio de Janeiro. Ano 12. Volume 19. Número 2. Maio a Agosto de 2018

Periódico Quadrimestral da Pós-Graduação Stricto Sensu em Direito Processual da UERJ

Patrono: José Carlos Barbosa Moreira (in mem.). ISSN 1982-7636. pp. 229-260

www.redp.uerj.br

Assentada tal premissa é que se pode questionar suas possíveis funções, como as pretendidas busca da verdade ou pacificação social. ${ }^{113}$ Sua função, em uma realidade condizente com a complexidade do fenômeno delitivo e com as limitações da atividade jurisdicional, é verificar a acusação penal em uma reconstrução histórica dos fatos passados imputados como um crime tipificado legalmente, a partir do lastro probatório produzido por iniciativa das partes. ${ }^{114}$ Assim, na visão de Paolo Ferrua, "a função do processo penal não pode ser outra que aquela de averiguar se é verdadeiro ou falso o enunciado formulado pela acusação". ${ }^{115}$ Mas, como visto, as funções do processo nunca podem se sobrepor ao seu fundamento, pois há uma relação de dependência entre tais premissas.

Portanto, "a instrumentalidade do processo penal a que corresponde sua legitimação, trata-se da proteção dos direitos fundamentais do hipossuficiente". ${ }^{116}$ Diante de tais conclusões, o papel da dogmática se sobressai, pois, o direito penal (e, de igual modo, o processual penal), "enquanto saber científico, deve ser construído e compreendido tendo como horizonte de sentido a restrição, mais hermética possível, ao mais intenso poder Estatal - o punitivo (potestas puniendi)". ${ }^{117}$ Embora considere-se as limitações da dogmática para o cumprimento de tais pretensões, ${ }^{118}$ pensa-se que há possíveis espaços

\footnotetext{
${ }^{113}$ Sobre isso, ver: KHALED JR., Salah H. A busca da verdade no processo penal. Para além da ambição inquisitorial. São Paulo: Atlas, 2013; VASCONCELLOS, Vinicius G. Lide na justiça criminal? Sobre a importância do conflito de interesses entre as partes processuais e sua irrelevância para a necessidade do Processo Penal. Revista Brasileira de Ciências Criminais, São Paulo, v. 119, p. 165-199, abr./jun. 2016.

114 "Com efeito, a definição do nulla poena sine iudicio requisita que se compreenda a função (re)cognitiva do processo, assumido como condição para fundamentar a obrigatoriedade da decisão que seja adotada, de modo a cobrar que esteja estruturado e seja capaz de se constituir em terreno jurídico de verificação e refutação das teses antagônicas deduzidas pela acusação e defesa." (PRADO, Geraldo. Prova penal $e$ sistema de controles epistêmicos. A quebra da cadeia de custódia das provas obtidas por métodos ocultos. São Paulo: Marcial Pons, 2014. p. 19).

115 FERRUA, Paolo. Gênese da reforma constitucional do "giusto processo" na Itália. Revista Brasileira de Direito Processual Penal, Porto Alegre, vol. 3, n. 2, p. 661-688, mai./ago. 2017. p. 673. De modo semelhante: BADARÓ, Gustavo H. A busca da verdade no processo penal e os seus limites: ainda e sempre o problema do prazo de duração da interceptação telefônica. In: SANTORO, Antonio E.; MADURO, Flávio M. (orgs.). Interceptação telefônica. Belo Horizonte: D’Plácido, 2016. p. 194-195.

116 GLOECKNER, Ricardo Jacobsen. Nulidades no Processo Penal. Introdução principiológica à teoria do ato processual irregular. Salvador: JusPodivm, 2013. p. 31. De modo semelhante: CHINNICI, Daniela. Giudizio Penale di Seconda Istanza e Giusto Processo. 2a ed. Torino: G. Giappichelli, 2009. p. 70 e 190. Conforme Montero Aroca, trata-se de "instrumento de garantia do direito de liberdade" (MONTERO AROCA, Juan. Proceso penal y libertad. Ensayo polémico sobre el nuevo proceso penal. Madrid: Thomson Civitas, 2008. p. 65) (tradução livre).

117 SCALCON, Raquel Lima. Ilícito e pena. Modelos opostos de fundamentação do direito penal contemporâneo. Rio de Janeiro: GZ Editora, 2013. p. 152.

${ }^{118}$ ANDRADE, Vera R. Pereira de. A ilusão de segurança jurídica. Do controle da violência à violência do controle penal. $2^{\mathrm{a}}$ ed. Porto Alegre: Livraria do Advogado, 2003. p. 34-36.
} 
Revista Eletrônica de Direito Processual - REDP.

Rio de Janeiro. Ano 12. Volume 19. Número 2. Maio a Agosto de 2018

Periódico Quadrimestral da Pós-Graduação Stricto Sensu em Direito Processual da UERJ

Patrono: José Carlos Barbosa Moreira (in mem.). ISSN 1982-7636. pp. 229-260

www.redp.uerj.br

para a consolidação de um saber crítico consistente, apto a fomentar constrangimentos democráticos aos abusos do poder punitivo. ${ }^{119}$

\section{Considerações finais}

Diante do exposto, considerando o atendimento dos objetivos almejados, deve-se retomar as problematizações que guiaram este estudo: 1) qual é o fundamento e a função essencial do processo penal?; 2) qual é a relação entre as fases procedimentais do processo penal e a sua função de um modo amplo?; 3) qual é a relação das fases procedimentais do processo penal entre si?

1. O fundamento do processo penal, sua razão de existir, é o reconhecimento de que, em um Estado democrático de direito, uma sanção penal (especialmente, prisão) somente pode ser imposta após a obtenção de uma condenação definitiva com total respeito às regras do devido processo penal. E, assim, ele adquire o sentido de ser um instrumento de limitação do poder punitivo ao condicionar a aplicação de uma sanção penal ao seu transcorrer e encerramento, em respeito às regras do devido processo. Sua função, em uma realidade condizente com a complexidade do fenômeno delitivo e com as limitações da atividade jurisdicional, é verificar a acusação penal em uma reconstrução histórica dos fatos passados imputados como um crime tipificado legalmente, a partir do lastro probatório produzido por iniciativa das partes.

2. Embora as funções específicas de cada fase sejam distintas, todas elas são partes integrantes do processo penal de um modo amplo. Assim, as finalidades específicas das fases procedimentais que o integram devem se guiar e se inserir nessa lógica, respeitando os seus princípios e reflexos. Mas, como visto, as funções do processo nunca podem se sobrepor ao seu fundamento, pois há uma relação de dependência entre tais premissas.

3. Na estruturação procedimental do processo penal, tende-se a uma centralidade do juízo oral, com um consequente direcionamento das demais fases para a sua primazia. Isso acarreta funções distintas e limitações cognitivas para cada fase, mas sem reduzir a importância de cada uma ou determinar a fragilização de direitos fundamentais, pois, como já exposto, todas as fases se orientam pela premissa comum do processo penal: ser um

\footnotetext{
${ }^{119}$ KHALED JR., Salah H.; ROSA, Alexandre Morais da. Neopenalismo e constrangimentos democráticos. Florianópolis: Empório do Direito, 2015. p. 41-44.
} 
Revista Eletrônica de Direito Processual - REDP.

Rio de Janeiro. Ano 12. Volume 19. Número 2. Maio a Agosto de 2018

Periódico Quadrimestral da Pós-Graduação Stricto Sensu em Direito Processual da UERJ

Patrono: José Carlos Barbosa Moreira (in mem.). ISSN 1982-7636. pp. 229-260

www.redp.uerj.br

instrumento de limitação do poder punitivo ao condicionar a aplicação de uma sanção

penal ao seu transcorrer e encerramento, em respeito às regras do devido processo.

\section{REFERÊNCIAS BIBLIOGRÁFICAS:}

ALBRECHT, Peter-Alexis. Criminologia. Uma Fundamentação para o Direito Penal. Rio de Janeiro: Editora Lumen Juris, 2010.

ALCÁCER GUIRAO, Rafael. El Derecho a una Segunda Instancia con Todas las Garantías. Valencia: Tirant lo Blanch, 2013.

ALMEIDA, Joaquim C. M. A contrariedade na instrução criminal. São Paulo: [s.n.], 1937.

AMARAL, Augusto Jobim do. Introdução à história das ideias do processo penal brasileiro. Revista História, ano 4, vol. 1, n. 1, p. 192-221, 2013.

ANDRADE, Vera R. Pereira de. A ilusão de segurança jurídica. Do controle da violência à violência do controle penal. $2^{\mathrm{a}}$ ed. Porto Alegre: Livraria do Advogado, 2003.

ANDRÉS IBÁÑEZ, Perfecto. Prueba y convicción judicial en el proceso penal. Buenos Aires: Hammurabi, 2009.

ARANGÜENA FANEGO, Coral. La doble instancia en el proceso penal. Criminalia, $\mathrm{n}$. 65, p. 03-42, jan./abr. 1999

ARMENTA DEU, Teresa. Juicio de acusación, imparcialidad del acusador y derecho de defensa. In: BACHMAIER WINTER, Lorena (coord.). Proceso penal y sistemas acusatorios. Madrid: Marcial Pons, 2008.

BADARÓ, Gustavo Henrique. Processo Penal. $2^{\mathrm{a}}$ ed. Rio de Janeiro: Elsevier, 2014.

BADARÓ, Gustavo Henrique. Manual dos Recursos Penais. São Paulo: RT, 2016.

BADARÓ, Gustavo H. A busca da verdade no processo penal e os seus limites: ainda e sempre o problema do prazo de duração da interceptação telefônica. In: SANTORO, Antonio E.; MADURO, Flávio M. (orgs.). Interceptação telefônica. Belo Horizonte: D'Plácido, 2016.

BARATTA, Alessandro. Criminologia Crítica e Crítica do Direito Penal. Rio de Janeiro: Revan, 2002.

BARROS, Flaviane de Magalhães. (Re)forma do Processo Penal. $2^{\mathrm{a}}$ ed. Belo Horizonte: Del Rey, 2009. 
Revista Eletrônica de Direito Processual - REDP.

Rio de Janeiro. Ano 12. Volume 19. Número 2. Maio a Agosto de 2018

Periódico Quadrimestral da Pós-Graduação Stricto Sensu em Direito Processual da UERJ

Patrono: José Carlos Barbosa Moreira (in mem.). ISSN 1982-7636. pp. 229-260

www.redp.uerj.br

BEDAQUE, José Roberto dos Santos. Direito e Processo. Influencia do direito material sobre o processo. $6^{\mathrm{a}}$ ed. São Paulo: Malheiros, 2011.

BELLINO, Silvia. La rinnovazione dell'instruttoria dibattimentale nel rito ordinario. In:

IANDOLO, Lucia (org.). La prova nel giudizio di appello. Torino: Giappichielli, 2014.

BINDER, Alberto M. La implementación de la nueva justicia penal adversarial. Buenos Aires: Ad-Hoc, 2012.

CAPONE, Arturo. Dopo Dan c. Moldavia. Per un processo di parti nell'appello penale. Rivista di Diritto Processuale, ano LXX, n. 4-5, p. 1007-1028, jul./out. 2015.

CAPPARELLI, Bruna; VASCONCELLOS, Vinicius G. Notas sobre a perene crise do princípio da obrigatoriedade da ação penal no ordenamento italiano. Revista Eletronica de Direito Processual, Rio de Janeiro, ano 11, vol. 18, n. 1, p. 118-149, jan.-abr. 2017. https://doi.org/10.12957/redp.2017.27994

CARVALHO, Salo. Antimanual de criminologia. $3^{\text {a }}$ ed. Rio de Janeiro: Lumen Juris, 2010.

CASARA, Rubens R. R. Mitologia Processual Penal. São Paulo: Saraiva, 2015.

CASARA, Rubens R. R.; MELCHIOR, Antonio Pedro. Teoria do Processo Penal brasileiro. Dogmática e crítica: conceitos fundamentais. Vol. 1. Rio de Janeiro: Lumen Juris, 2013.

CASTANHEIRA NEVES, Antonio. Entre o "legislador", a "sociedade” e o "juiz" ou entre "sistema", "função" e "problema" - os modelos actualmente alternativos de realização jurisdicional do direito. Boletim da Faculdade de Direito da Universidade de Coimbra, vol. LXXIV, p. 1-44, 1998.

CHINNICI, Daniela. L'Immediatezza nel Processo Penale. Milano: Giuffrè, 2005.

CHINNICI, Daniela. Giudizio Penale di Seconda Istanza e Giusto Processo. $2^{\mathrm{a}}$ ed. Torino: Giappichelli, 2009.

CHIOVENDA, Giuseppe. A oralidade e a prova. Revista Forense, v. 74, p. 232-248, mai. 1939.

CHOUKR, Fauzi Hassan. Garantias constitucionais na investigação criminal. $2^{\mathrm{a}}$ ed. Rio de Janeiro: Lumen Juris, 2001.

CHOUKR, Fauzi Hassan. Processo Penal de Emergência. Rio de Janeiro: Lumen Juris, 2002. 
Revista Eletrônica de Direito Processual - REDP.

Rio de Janeiro. Ano 12. Volume 19. Número 2. Maio a Agosto de 2018

Periódico Quadrimestral da Pós-Graduação Stricto Sensu em Direito Processual da UERJ

Patrono: José Carlos Barbosa Moreira (in mem.). ISSN 1982-7636. pp. 229-260

www.redp.uerj.br

CINTRA, Antonio C. A.; GRINOVER, Ada P.; DINAMARCO, Cândido R. Teoria Geral do Processo. $24^{\mathrm{a}}$ ed. São Paulo: Malheiros, 2008.

CRUZ, Rogério S. M. Garantias Processuais nos Recursos Criminais. $2^{\mathrm{a}}$ ed. São Paulo: Atlas, 2013.

DEL POZZO, Carlo Umberto. L'Appello nel processo penale. Torino: UTET, 1957.

DIAS, Jorge de Figueiredo. Acordos sobre a sentença em processo penal. O "fim" do Estado de Direito ou um novo "princípio"? Porto: Conselho Distrital do Porto, 2011.

DINAMARCO, Cândido Rangel. A instrumentalidade do processo. $15^{\mathrm{a}}$ ed. São Paulo: Malheiros, 2013.

DIVAN, Gabriel. Processo Penal e Política Criminal: uma reconfiguração da justa causa para a ação penal. Porto Alegre: Elegantia Juris, 2015.

DIVAN, Gabriel A. Crítica científica de "A colaboração premiada como instrumento de política criminal" - Um adendo sobre a necessária visão político-criminal do processo penal. Revista Brasileira de Direito Processual Penal, Porto Alegre, vol. 3, n. 1, p. 417-428, jan./abr. 2017. https://doi.org/10.22197/rbdpp.v3i1.55

DUCE, Mauricio; MARÍN, Felipe; RIEGO, Cristián. Reforma a los procesos civiles orales: consideraciones desde el debido proceso y calidad de la información. In: CABEZÓN, Andrea. ARANEDA, Sandra. (ed.). Justicia Civil: perspectivas para una reforma en América Latina. Santiago: CEJA, 2008.

DUCE, Mauricio; RIEGO, Cristián. Proceso Penal. Santiago: Editorial Juridica de Chile, 2011.

DUCLERC, Elmir. Por uma teoria do processo penal. Florianópolis: Empório do Direito, 2015.

FARIA COSTA, José Francisco de. Noções fundamentais de direito penal. $2^{\mathrm{a}}$ ed. Coimbra: Coimbra Editora, 2009.

FATTIBENE, Rosanna. Il doppio grado de giudizio tra garanzia dei diritti $e$ organizzazione giudiziairia. Profili di comparazione. Torino: Giappichelli, 2010.

FERNANDES, Antonio Scarance. Reação defensiva à imputação. São Paulo: RT, 2002.

FERNANDES, Antonio Scarance. Teoria Geral do Procedimento e O Procedimento no Processo Penal. São Paulo: RT, 2005.

FERNANDES, Fernando. O processo penal como instrumento de política criminal. Coimbra: Almedina, 2001. 
Revista Eletrônica de Direito Processual - REDP.

Rio de Janeiro. Ano 12. Volume 19. Número 2. Maio a Agosto de 2018

Periódico Quadrimestral da Pós-Graduação Stricto Sensu em Direito Processual da UERJ

Patrono: José Carlos Barbosa Moreira (in mem.). ISSN 1982-7636. pp. 229-260

www.redp.uerj.br

FERRETI, Carlos del Río. Estudio sobre el derecho al recurso en el proceso penal.

Estudios Constitucionales, ano 10, n. 01, p. 245-288, 2012. https://doi.org/10.4067/s0718-52002012000100007

FERRUA, Paolo. Gênese da reforma constitucional do "giusto processo" na Itália. Revista

Brasileira de Direito Processual Penal, Porto Alegre, vol. 3, n. 2, p. 661-688, mai./ago. 2017. https://doi.org/10.22197/rbdpp.v3i2.61

FUENTES MAUREIRA, Claudio. Derecho a recurso y el estándar fijado en el fallo Herrera Ulloa: una lectura hacia su compatibilidad con los sistemas procesales penales acusatorios. Revista CEJIL, ano IV, n. 05, p. 74-82, dez. 2009.

GAITO, Alfredo. Verso una crisi evolutiva per il giudizio d'appello. Archivio Penale, n. 02, p. 1-7, 2012.

GAITO, Alfredo. Riformiamo le impugnazioni penali senza rinunciare al giusto processo. Archivio Penale, n. 02, p. 01-15, 2012.

GARLAND, David. Culture of Control. Chicago: The University of Chicago Press, 2001.

GIACOMOLLI, Nereu José. O Devido Processo Penal. Abordagem conforme a Constituição Federal e o Pacto de São José da Costa Rica. São Paulo: Atlas, 2014.

GLOECKNER, Ricardo Jacobsen. Nulidades no Processo Penal. Introdução principiológica à teoria do ato processual irregular. Salvador: JusPodivm, 2013.

GOMES, Décio Luiz Alonso. Prova e imediação no processo penal. Salvador: Juspodivm, 2016.

GÓMEZ ORGANEJA, Emilio. Comentarios a la Ley de Enjuiciamiento Criminal. Tomo I. Barcelona: Bosch, 1951.

GONZÁLEZ POSTIGO, Leonel. La oralidad en la etapa recursiva del proceso penal chileno. Las audiencias ante la Corte de Apelaciones de Santiago. Revista Derecho Penal, ano III, n. 07, p. 333-374, mai. 2014.

GRINOVER, Ada Pellegrini. Ensaio sobre a processualidade. Fundamentos para uma nova teoria geral do processo. Brasília: Gazeta, 2016.

GRINOVER, Ada Pellegrini; GOMES FILHO, Antonio M.; FERNANDES, Antonio S. As Nulidades no Processo Penal. $7^{\mathrm{a}}$ ed. São Paulo: RT, 2001.

HERBEL, Gustavo A. Derecho del imputado a revisar su condena. Motivación del fallo y derecho al recurso a través de las garantías constitucionales. Buenos Aires: Hammurabi, 2013. 
Revista Eletrônica de Direito Processual - REDP.

Rio de Janeiro. Ano 12. Volume 19. Número 2. Maio a Agosto de 2018

Periódico Quadrimestral da Pós-Graduação Stricto Sensu em Direito Processual da UERJ

Patrono: José Carlos Barbosa Moreira (in mem.). ISSN 1982-7636. pp. 229-260

www.redp.uerj.br

IACOVIELLO, Francesco M. La motivazione dela sentenza penale e il suo controllo in cassazione. Milano: Giuffrè, 1997.

ILLUMINATI, Giulio. El sistema acusatorio en Italia. In: BACHMAIER WINTER, Lorena (coord.). Proceso penal y sistemas acusatorios. Madrid: Marcial Pons, 2008.

JOBIM, Marco Félix. Cultura, escolas e fases metodológicas do processo. $3^{\mathrm{a}}$ ed. Porto Alegre: Livraria do Advogado, 2016.

JUGO, Gabriela. El derecho de recurrir la sentencia penal condenatoria y los instrumentos internacionales de derechos humanos. In: GARCÍA, Luis M. (Coord.). Los derechos humanos en el proceso penal: función en el derecho interno, detención, prisión preventiva, recurso contra la sentencia de condena. Buenos Aires: Ábaco de Rodolfo Depalma, 2002.

KHALED JR., Salah H. A busca da verdade no processo penal. Para além da ambição inquisitorial. São Paulo: Atlas, 2013.

LARA LÓPEZ, Antonio Maria. El recurso de apelación y la segunda instancia penal. Cizur Menor: Aranzadi, 2014.

LETELIER LOYOLA, Enrique. El Derecho Fundamental al Recurso en el Proceso Penal. Barcelona: Atelier, 2013.

LOPES JR., Aury. Direito processual penal. $9^{\mathrm{a}}$ ed. São Paulo: Saraiva, 2012.

LOPES JR., Aury; GLOECKNER, Ricardo J. Investigação Preliminar no Processo Penal. $6^{\mathrm{a}}$ ed. São Paulo: Saraiva, 2014.

MACHADO, André Augusto Mendes. Investigação criminal defensiva. São Paulo: RT, 2010.

MACHADO, Antônio Alberto. Teoria Geral do Processo Penal. São Paulo: Atlas, 2009.

MAIER, Julio B. J. Derecho Procesal Penal. Tomo I. $2^{\text {a }}$ ed. Buenos Aires: Del Puerto, 2004.

MALAN, Diogo. Ideologia política de Francisco Campos: influência na legislação processual penal brasileira (1937-1941). In: PRADO, Geraldo; MALAN, Diogo (org.). Autoritarismo e Processo Penal Brasileiro. Rio de Janeiro: Lumen Juris, 2015.

MARINHO MARQUES, Leonardo Augusto. O princípio da oralidade e a descentralização da informação relevante no processo penal. Revista de Estudos Criminais, Porto Alegre, v. 10. n. 46, p. 157-170, jul./set. 2012. 
Revista Eletrônica de Direito Processual - REDP.

Rio de Janeiro. Ano 12. Volume 19. Número 2. Maio a Agosto de 2018

Periódico Quadrimestral da Pós-Graduação Stricto Sensu em Direito Processual da UERJ

Patrono: José Carlos Barbosa Moreira (in mem.). ISSN 1982-7636. pp. 229-260

www.redp.uerj.br

MASSA, Michele. Contributo allo studio dell'appello nel processo penale. Milano:

Giuffrè, 1969.

MCBRIDE, Jeremy. Human rights and criminal procedure. The case law of the European

Court of Human Rights. Strasbourg: Council of Europe Publishing, 2009.

MONTERO AROCA, Juan. Proceso penal y libertad. Ensayo polémico sobre el nuevo proceso penal. Madrid: Thomson Civitas, 2008.

MONTESQUIEU, Charles de Secondat. O espírito das leis. São Paulo: Martins Fontes, 1996.

MORATO, Francisco. A oralidade. Revista Forense, Rio de Janeiro, vol. 74, fasc. 418, p. 141-148, abr. 1938.

MOURA, Maria Thereza de Assis. Justa causa para a ação penal: doutrina e jurisprudência. São Paulo: RT, 2001.

PASCHOAL, Jorge Coutinho. O prejuízo e as nulidades processuais penais. Um estudo à luz da jurisprudência do Supremo Tribunal Federal e do Superior Tribunal de Justiça. Rio de Janeiro: Lumen Juris, 2014.

PASTOR, Daniel R. El llamado "impacto" de los tratados de derechos humanos en el derecho interno con especial referencia al derecho procesal penal. Cuadernos de Doctrina y Jurisprudencia Penal, Buenos Aires, ano 05, n. 09, p. 41-57, 1999.

PASTOR, Daniel R. La nueva imagen de la casación penal. Evolución histórica y futuro de la dogmática de la impugnación en el derecho procesal penal. Buenos Aires: AdHoc, 2001.

PASTOR, Daniel R. Los alcances del derecho del imputado a recurrir la sentencia. ¿La casación penal condenado? A propósito del caso 'Herrera Ulloa vs. Costa Rica' de la Corte Interamericana de Derechos Humanos. Revista de Ciencias Penales de Costa Rica, n. 23, p. 47-51, 2005.

PASTOR, Daniel. La ideología penal de ciertos pronunciamientos de los órganos del sistema interamericano de derechos humanos: ¿garantías para el imputado, para la víctima o para el aparato represivo del estado? In: AMBOS, Kai; MALARINO, Ezequiel; ELSNER, Gisela (editores). Sistema interamerica de protección de los derechos humanos y derecho penal internacional. Tomo II. Berlim: KonradAdenauer-Stiftung, 2011. 
Revista Eletrônica de Direito Processual - REDP.

Rio de Janeiro. Ano 12. Volume 19. Número 2. Maio a Agosto de 2018

Periódico Quadrimestral da Pós-Graduação Stricto Sensu em Direito Processual da UERJ

Patrono: José Carlos Barbosa Moreira (in mem.). ISSN 1982-7636. pp. 229-260

www.redp.uerj.br

PAULA, Leonardo Costa de. As Nulidades no Processo Penal. Sua compreensão por meio

da afirmação do direito como controle ao poder de punir. Curitiba: Juruá, 2013.

PERONI, Francesco. L'istruzione debattimentale nel giudizio d'appello. Milão: CEDAM, 1995.

PRADO, Geraldo. Prova penal e sistema de controles epistêmicos. A quebra da cadeia de custódia das provas obtidas por métodos ocultos. São Paulo: Marcial Pons, 2014.

RAMOS, André de Carvalho. Teoria Geral dos Direitos Humanos na Ordem Internacional. $4^{\mathrm{a}}$ ed. São Paulo: Saraiva, 2014.

RICHARD GONZÁLEZ, Manuel. La impugnación y revisión de la prueba mediante los recursos ordinarios y extraordinarios en el proceso penal. In: LLUCH, Xavier Abel; GONZÁLEZ, Manuel Richard (Dir.). Estudios sobre prueba penal: actos de investigación y medios de prueba en el proceso penal: diligencias de instrucción, entrada y registro, intervención de comunicaciones, valoración y revisión de la prueba en vía de recurso. Madrid: La Ley, 2013.

RIEGO, Cristian. Los regímenes recursivos en los sistemas procesales penales acusatorios en las Américas: aspectos generales. In: ANUARIO de derecho penal 20102011. Buenos Aires: Ad-Hoc, 2012.

ROSA, Alexandre Morais da; AMARAL, Augusto Jobim do. Cultura da Punição. A ostentação do horror. Rio de Janeiro: Lumen Juris, 2014.

SAAD, Marta. O direito de defesa no inquérito policial. São Paulo: RT, 2004.

SAAVEDRA, Giovani Agostini; VASCONCELLOS, Vinicius G. Expansão do Direito Penal e Relativização dos Fundamentos do Direito Penal. Revista de Estudos Criminais, São Paulo, nº. 42, p. 123-142, jul./set. 2011.

SANTOS, Bartira M. de Miranda. Defesa Social. Uma visão crítica. São Paulo: Estúdio, 2015.

SCALCON, Raquel Lima. Ilícito e pena. Modelos opostos de fundamentação do direito penal contemporâneo. Rio de Janeiro: GZ Editora, 2013.

SILVA SÁNCHEZ, Jesús-María. La Expansión del Derecho penal. $3^{\mathrm{a}}$ edição. Madrid: Edisofer, 2011.

SIMON, Jonathan. Governing Through Crime. How the war on crime transformed american democracy and created a culture of fear. Oxford: Oxford University Press, 2007. 
Revista Eletrônica de Direito Processual - REDP.

Rio de Janeiro. Ano 12. Volume 19. Número 2. Maio a Agosto de 2018

Periódico Quadrimestral da Pós-Graduação Stricto Sensu em Direito Processual da UERJ

Patrono: José Carlos Barbosa Moreira (in mem.). ISSN 1982-7636. pp. 229-260

www.redp.uerj.br

TAORMINA, Paolo. L'Essenzialità del Procedimento Penale. Napoli: Jovene, 1974. p

TAPIA FERNÁNDEZ, Isabel. La implantación generalizada de la segunda instancia en el proceso penal. Presente y futuro. Madri: Civitas, 2011.

TASSARA, Lucas. ¿Hasta donde llega el control de una sentencia? In: PASTOR, Daniel (dir.); GUZMÁN, Nicolás (coord.). Problemas actuales del Derecho Procesal Penal. Buenos Aires: Ad Hoc, 2012.

TUCCI, Rogério Lauria. Direitos e garantias individuais no processo penal brasileiro. $4^{\mathrm{a}}$ ed. São Paulo: RT, 2011.

VASCONCELLOS, Vinicius G. Lide na justiça criminal? Sobre a importância do conflito de interesses entre as partes processuais e sua irrelevância para a necessidade do Processo Penal. Revista Brasileira de Ciências Criminais, São Paulo, v. 119, p. 165199, abr./jun. 2016.

VILARES, Fernanda R.; BEDIN, Guilherme A. C.; CASTRO, Pedro M. A. Investigação criminal: o Projeto de Código de Processo Penal e investigação defensiva. Revista Brasileira de Ciências Criminais, São Paulo, v. 22, n. 107, p. 309-336, mar./abr. 2014. WACQUANT, Loïc. Punir os pobres. A nova gestão da miséria nos Estados Unidos. $3^{\mathrm{a}}$ ed. Rio de Janeiro: Revan, 2007.

YÁÑEZ VELASCO, Ricardo. Derecho al recurso en el proceso penal. Nociones fundamentales y teoría constitucional. Valencia: Tirant Lo Blanch, 2001.

ZAFFARONI, Eugenio Raúl. Em busca das penas perdidas. A perda de legitimidade do sistema penal. Rio de Janeiro: Revan, 2014. 